\title{
Comparison of cRGDfK Peptide Probes with Appended Shielded Heptamethine Cyanine Dye (s775z) for Near Infrared Fluorescence Imaging of Cancer
}

\author{
Rananjaya S. Gamage, Dong-Hao Li, Cynthia L Schreiber, and Bradley D. Smith* \\ Department of Chemistry and Biochemistry, 251 Nieuwland Science Hall \\ University of Notre Dame, IN 46556-5670, USA \\ *smith.115@nd.edu
}

\section{Table of contents}

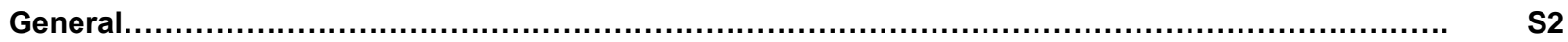

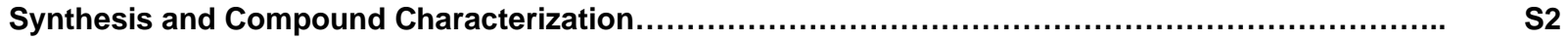

Photophysical Properties..................................................................................... $\quad$ S14

Bovine Serum Albumin Binding Studies.................................................................. S16

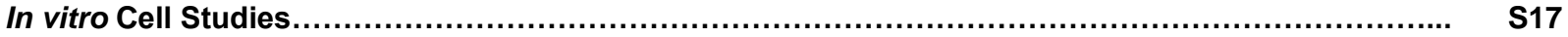

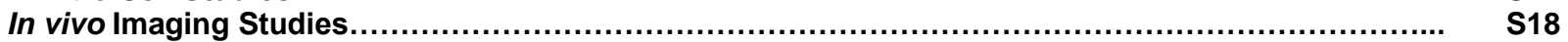




\section{General}

Reagents and solvents were purchased from Sigma-Aldrich, VWR, Oakwood, Thermo Fisher and TCI and used without further purification unless stated otherwise. Column chromatography was performed using Biotage Sfär columns. ${ }^{1} \mathrm{H}$ NMR spectra were recorded on a Bruker 500 NMR spectrometer. Chemical shifts are presented in ppm and referenced by residual solvent peak. High-resolution mass spectrometry (HRMS) was performed using a time-of-flight (TOF) analyzer with electrospray ionization (ESI). Absorption spectra were recorded on an Evolution $201 \mathrm{UV} / \mathrm{vis}$ spectrometer with Thermo Insight software. Fluorescence spectra were collected on a Horiba Fluoromax-4 fluorometer with FluoroEssence software. Analyte solutions were prepared in phosphate buffered saline (Thermo Fisher). All absorption and fluorescence spectra were collected using quartz cuvettes $(1 \mathrm{~mL}, 1 \mathrm{~cm}$ path length; for emission spectra, slit width $=3 \mathrm{~nm})$.

\section{Synthesis and Compound Characterization}

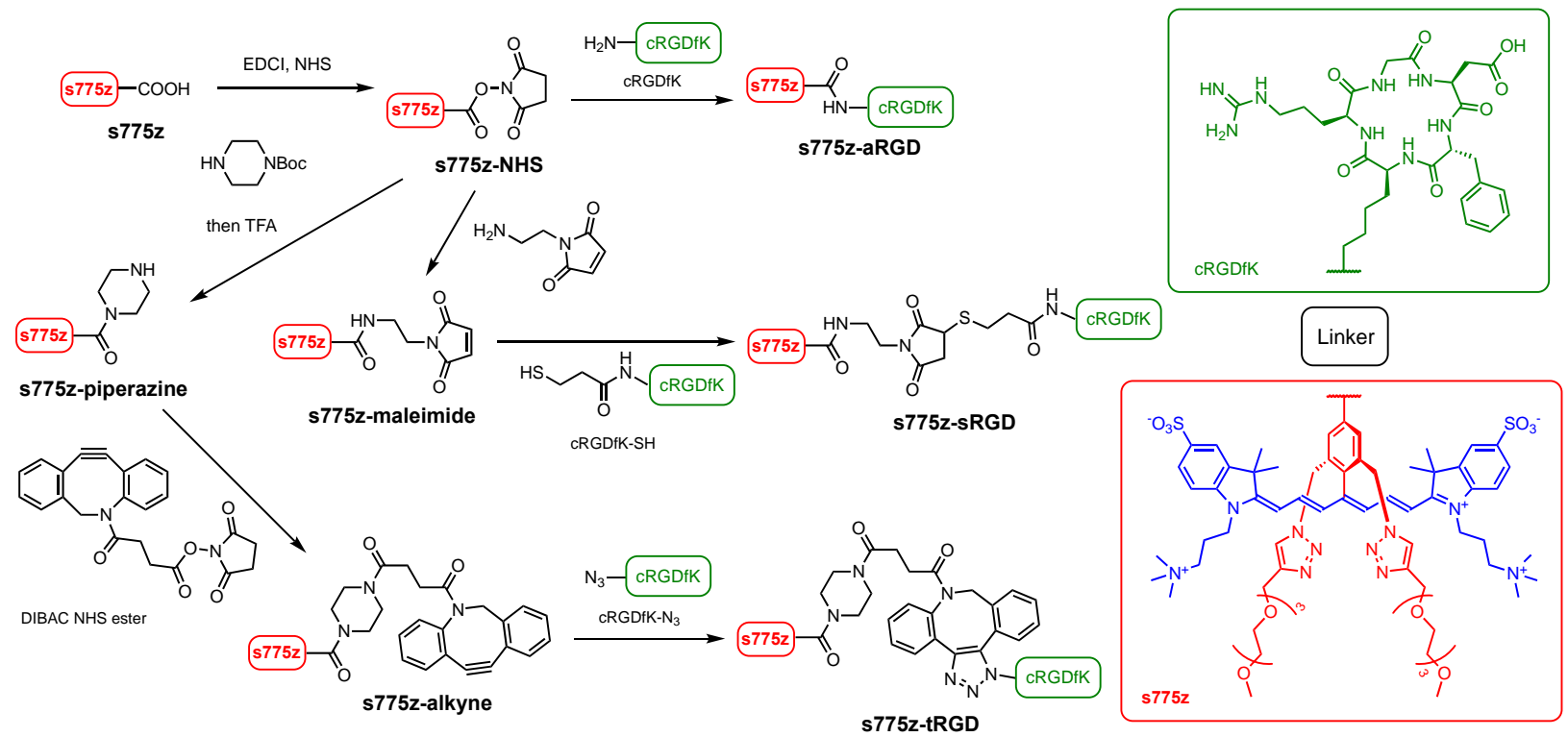

Scheme S1. (Copy of manuscript Scheme 2) Synthesis and characterization of $\mathbf{s 7 7 5 z}$ and $\mathbf{s 7 7 5 z - a R G D}$ have been reported previously by our group. ${ }^{1}$ DIBAC NHS ester ${ }^{2}, \mathrm{cRGDFK} \mathrm{SH}^{3}$ and $\mathrm{CRGDfK}-\mathrm{N}_{3}{ }^{4}$ were synthesized according to literature procedures. 
Zwitterionic pentamethine cyanine dye $650 \mathrm{z}$ was synthesized according to a literature procedure. ${ }^{5}$

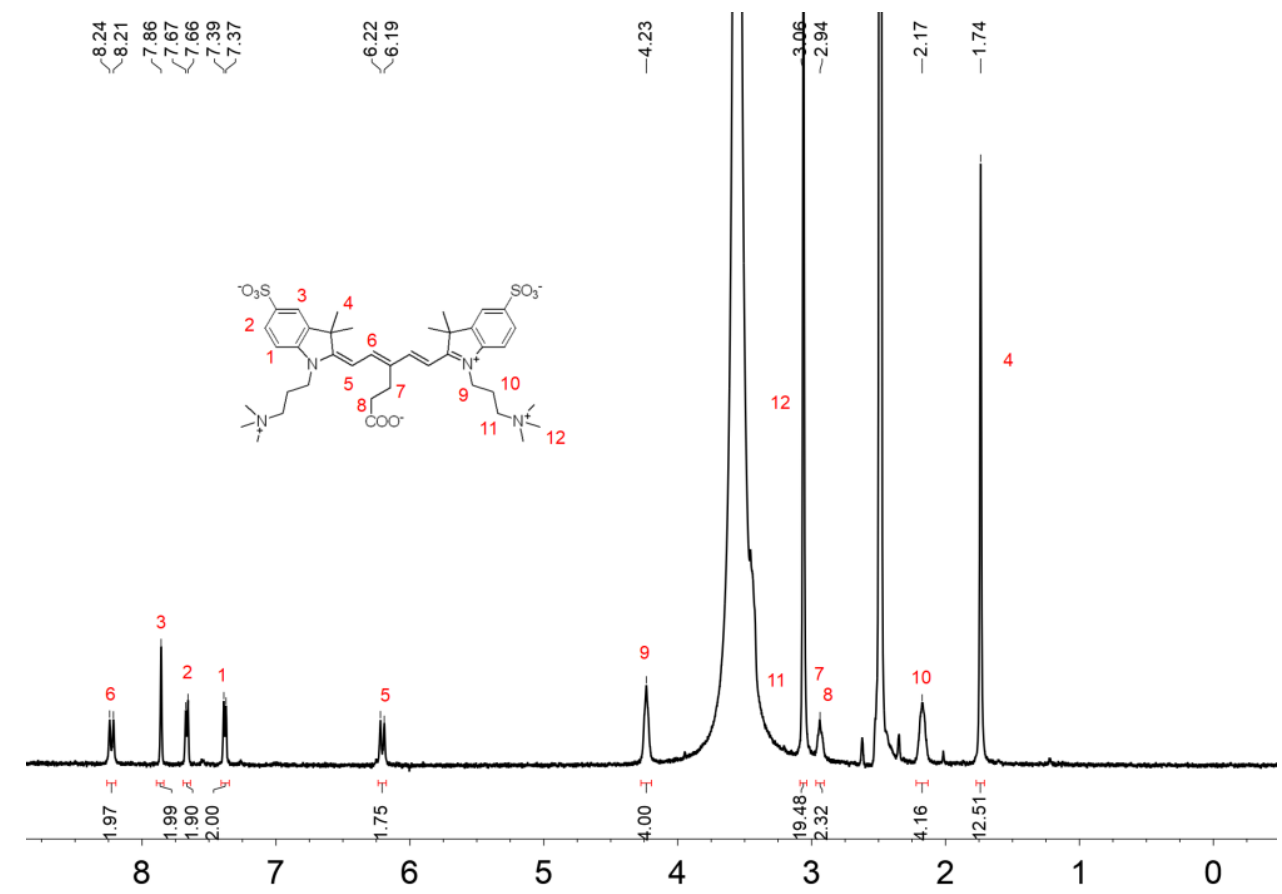

Figure S1. ${ }^{1} \mathrm{H}$ NMR spectrum $\left(500 \mathrm{MHz}\right.$, DMSO- $\left.d_{6}, 25^{\circ} \mathrm{C}\right)$ of $650 \mathrm{z}$
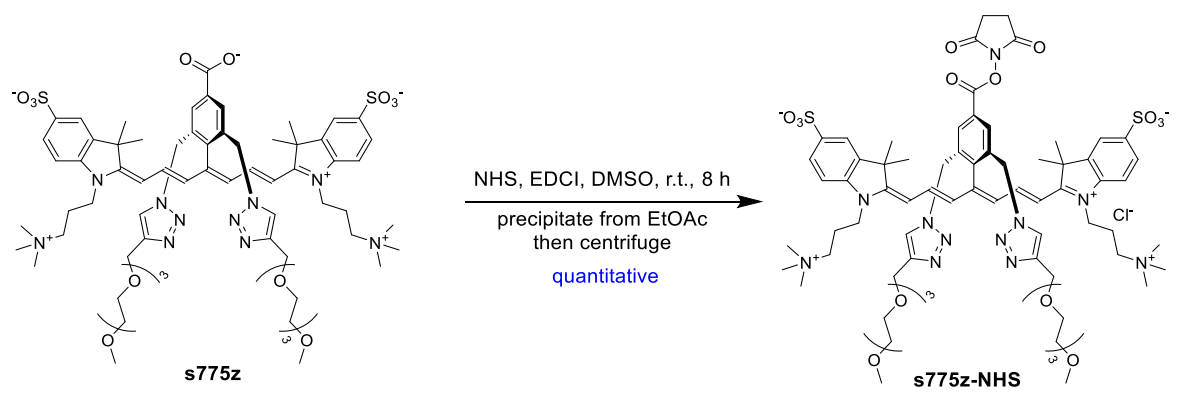

Scheme S2. Synthesis of s775z-NHS

A mixture of the s775z, N-hydroxysuccinimide (3 eq) and $\mathrm{N}$-(3-dimethylaminopropyl)-N'-ethylcarbodiimide hydrochloride (3 eq) in DMSO $(0.1 \mathrm{~mL}$ for $1 \mathrm{mg}$ of $\mathbf{s} 775 \mathrm{z})$ was stirred at room temperature for $8 \mathrm{~h}$ in the dark. The reaction mixture was transferred into a centrifuge tube. Ethyl acetate $(5 \mathrm{~mL}$ for $1 \mathrm{~mL}$ of DMSO) was added to the tube and mixture was centrifuged at $3600 \mathrm{rpm}$ for $5 \mathrm{~min}$. The supernatant was discarded and the green solid was washed with ethyl acetate $(2 \mathrm{x})$ and diethyl ether (1x) then dried in vacuo to afford s775z-NHS with quantitative yield.

${ }^{1} \mathrm{H}$ NMR $\left(500 \mathrm{MHz}, \mathrm{D}_{2} \mathrm{O}, 25^{\circ} \mathrm{C}\right) \delta(\mathrm{ppm}): 8.67(\mathrm{~s}, 2 \mathrm{H}), 7.99(\mathrm{~s}, 2 \mathrm{H}), 7.72(\mathrm{~d}, J=8.4 \mathrm{~Hz}, 2 \mathrm{H}), 7.66(\mathrm{~s}, 2 \mathrm{H}), 7.25(\mathrm{~d}, J=$ $8.4 \mathrm{~Hz}, 2 \mathrm{H}), 6.68(\mathrm{~d}, J=13.2 \mathrm{~Hz}, 2 \mathrm{H}), 6.57(\mathrm{dd}, J=13.2,13.2 \mathrm{~Hz}, 2 \mathrm{H}), 6.22(\mathrm{~d}, J=13.5 \mathrm{~Hz}, 2 \mathrm{H}), 5.52(\mathrm{~s}, 4 \mathrm{H}), 4.33(\mathrm{~s}$, 4H), 4.08 (br s, 4H), 3.45-3.30 (m, 28H), $3.19(\mathrm{~s}, 6 \mathrm{H}), 3.05(\mathrm{~s}, 18 \mathrm{H}), 2.98(\mathrm{~s}, 4 \mathrm{H}), 2.19(\mathrm{br} \mathrm{s}, 4 \mathrm{H}), 1.02(\mathrm{~s}, 12 \mathrm{H})$.

HRMS (ESI-TOF) m/z: $[\mathrm{M}+\mathrm{H}]^{2+}$ calcd for $\mathrm{C}_{72} \mathrm{H}_{101} \mathrm{~N}_{11} \mathrm{O}_{18} \mathrm{~S}_{2}{ }^{2+} 735.8378$, found 735.8379 . 


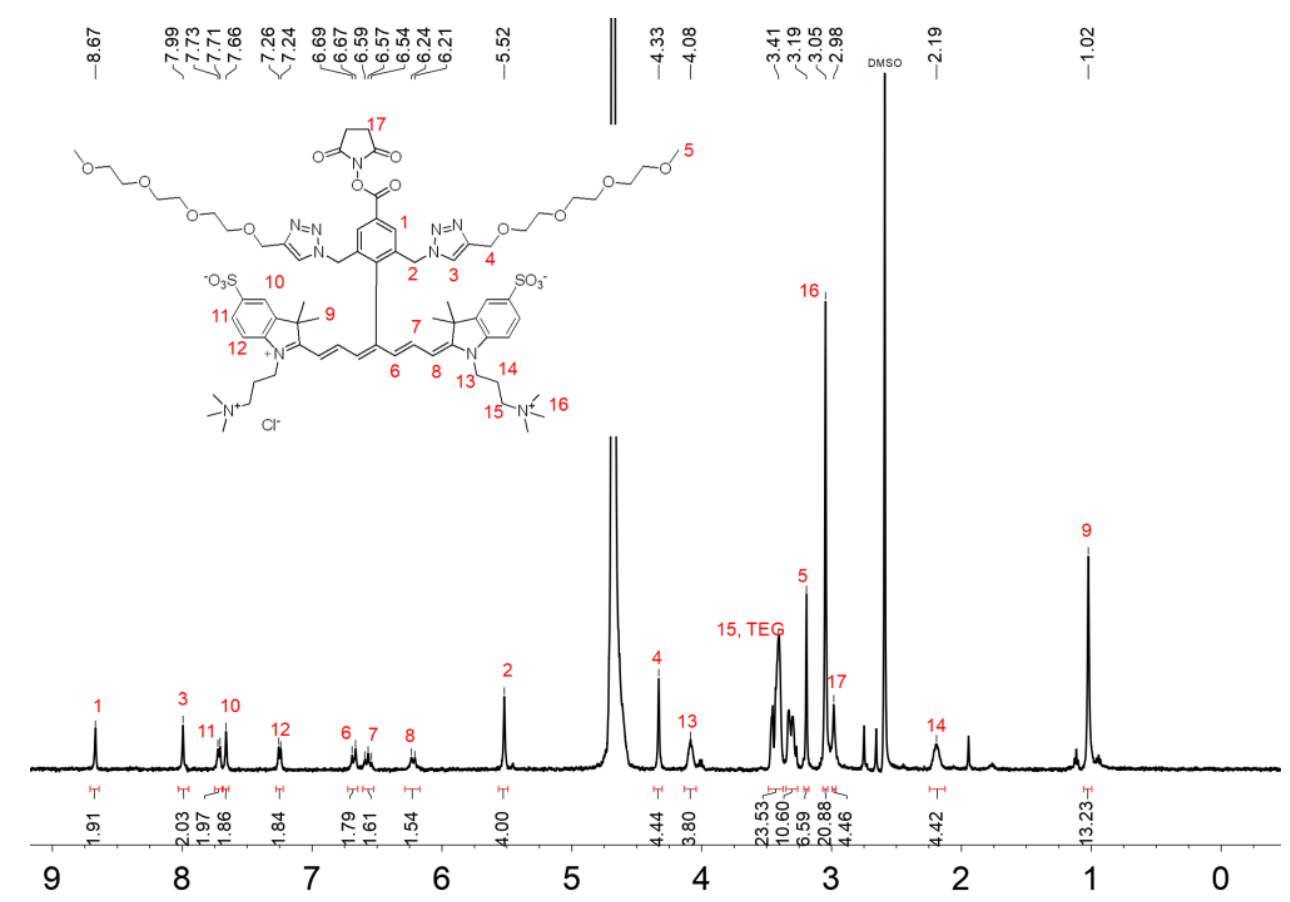

Figure S2. ${ }^{1} \mathrm{H}$ NMR spectrum $\left(500 \mathrm{MHz}, \mathrm{D}_{2} \mathrm{O}, 25^{\circ} \mathrm{C}\right)$ of $\mathbf{s} 775 z-\mathrm{NHS}$

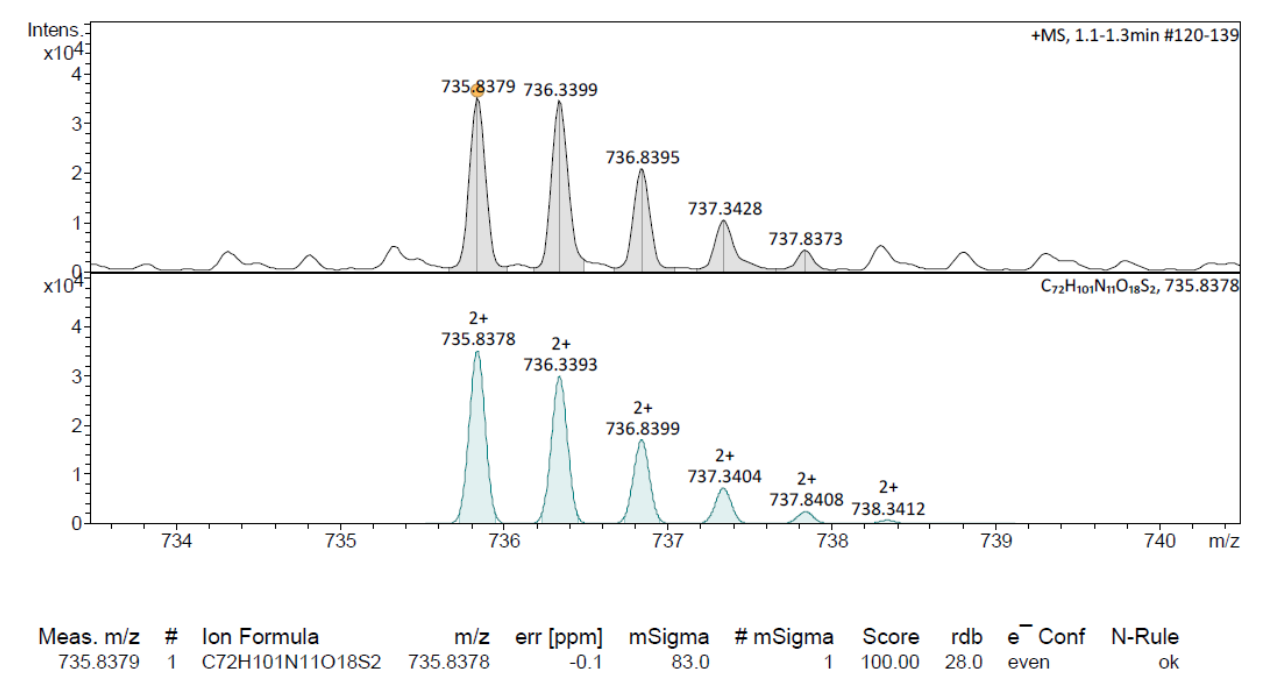

Figure S3. HRMS spectrum of s775z-NHS 

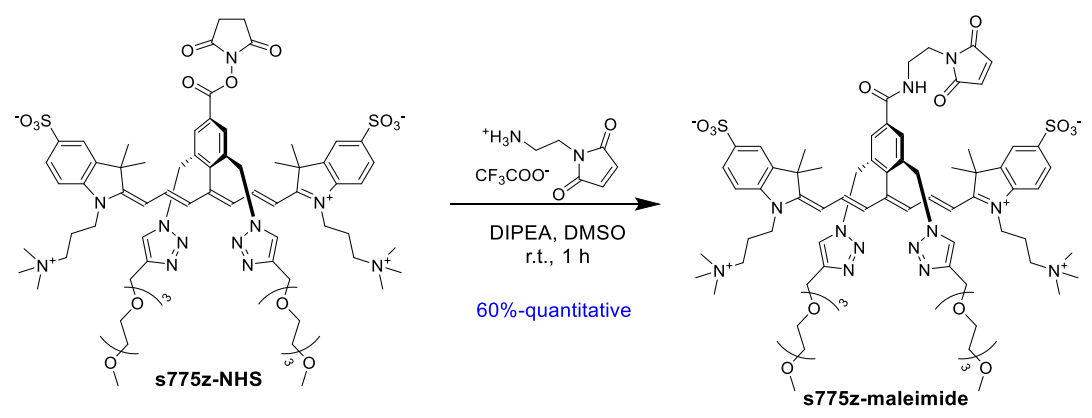

\section{Scheme S3. Synthesis of s775z-maleimide}

A mixture of the s775z-NHS, $\mathrm{N}$-(2-aminoethyl) maleimide trifluoroacetate salt ( 3 eq) and DIPEA (6 eq) in DMSO (0.1 $\mathrm{mL}$ for $1 \mathrm{mg}$ of $\mathbf{s} 775 \mathbf{z}-\mathbf{N H S}$ ) was stirred at room temperature for $1 \mathrm{~h}$ in the dark.

For small scale reactions $(<10 \mathrm{mg})$, the reaction was transferred into a centrifuge tube. Ethyl acetate $(5 \mathrm{~mL}$ for $1 \mathrm{~mL}$ of DMSO) was added to the tube and mixture was centrifuged at $3600 \mathrm{rpm}$ for $5 \mathrm{~min}$. The supernatant was discarded and the green solid was washed with ethyl acetate $(2 x)$ and diethyl ether $(1 x)$ then dried in vacuo to afford $\mathbf{s 7 7 5 z - m a l e i m i d e}$ with quantitative yield.

For larger scale reactions ( $>50 \mathrm{mg}$ ), there is significantly increased amount of by product. The reaction mixture was directly purified by reverse phase column chromatography $\left(\mathrm{C} 18,20 \%-35 \% \mathrm{MeOH}\right.$ in $\mathrm{H}_{2} \mathrm{O}$ with $\left.0.5 \% \mathrm{TFA}\right)$ to afford s775z-maleimide (green solid, $\sim 60 \%$ yield).

${ }^{1} \mathrm{H}$ NMR $\left(500 \mathrm{MHz}, \mathrm{D}_{2} \mathrm{O}, 25^{\circ} \mathrm{C}\right) \delta(\mathrm{ppm}): 8.10(\mathrm{~s}, 2 \mathrm{H}), 7.95(\mathrm{~s}, 2 \mathrm{H}), 7.70(\mathrm{~d}, J=8.5 \mathrm{~Hz}, 2 \mathrm{H}), 7.64(\mathrm{~s}, 2 \mathrm{H}), 7.23(\mathrm{~d}, J=$ $8.5 \mathrm{~Hz}, 2 \mathrm{H}), 6.77(\mathrm{~s}, 2 \mathrm{H}), 6.70(\mathrm{~d}, J=13.1 \mathrm{~Hz}, 2 \mathrm{H}), 6.59(\mathrm{dd}, J=13.1,13.1 \mathrm{~Hz}, 2 \mathrm{H}), 6.21(\mathrm{~d}, J=13.1 \mathrm{~Hz}, 2 \mathrm{H}), 5.45(\mathrm{~s}$, $4 \mathrm{H}), 4.33(\mathrm{~s}, 4 \mathrm{H}), 4.07$ (br s, 4H), $3.73(\mathrm{br} \mathrm{s}, 2 \mathrm{H}), 3.60(\mathrm{br} \mathrm{s}, 2 \mathrm{H}), 3.44-3.28(\mathrm{~m}, 28 \mathrm{H}), 3.18(\mathrm{~s}, 6 \mathrm{H}), 3.03(\mathrm{~s}, 18 \mathrm{H}), 2.18$ (br s, 4H), 0.97 (s, 12H).

HRMS (ESI-TOF) m/z: [M] calcd for $\mathrm{C}_{74} \mathrm{H}_{103} \mathrm{~N}_{12} \mathrm{O}_{17} \mathrm{~S}_{2}+1495.7000$, found 1495.7120 .

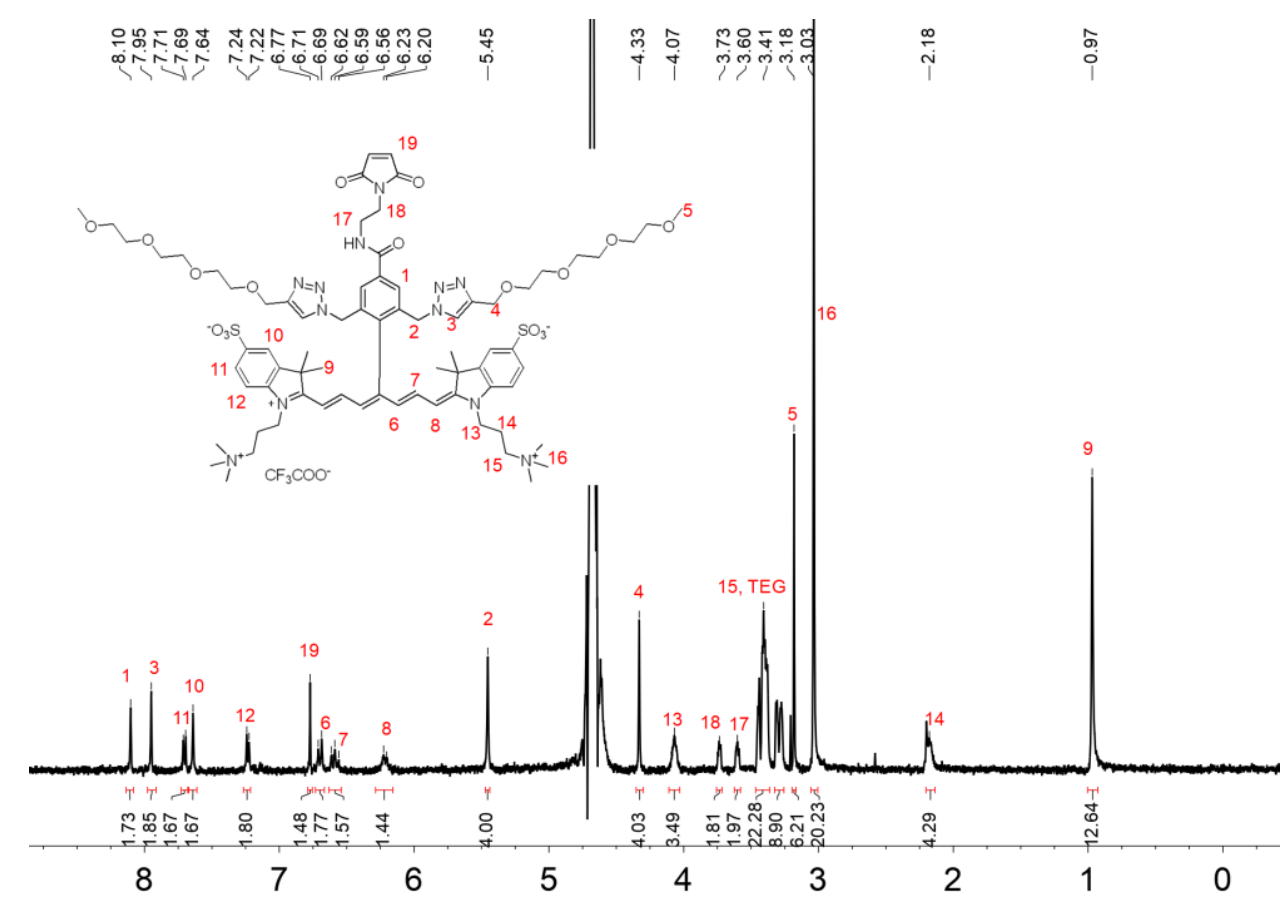

Figure S4. ${ }^{1} \mathrm{H}$ NMR spectrum $\left(500 \mathrm{MHz}, \mathrm{D}_{2} \mathrm{O}, 25^{\circ} \mathrm{C}\right)$ of $\mathbf{s} 775 z$-maleimide 


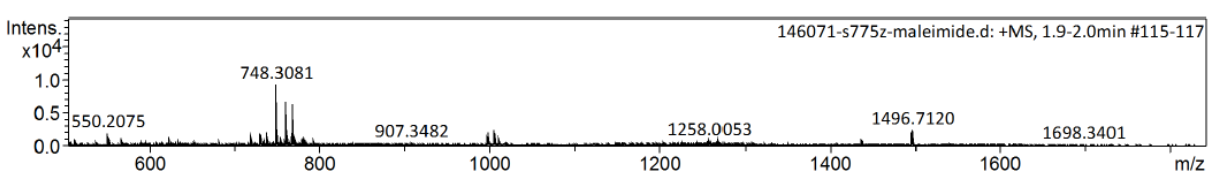

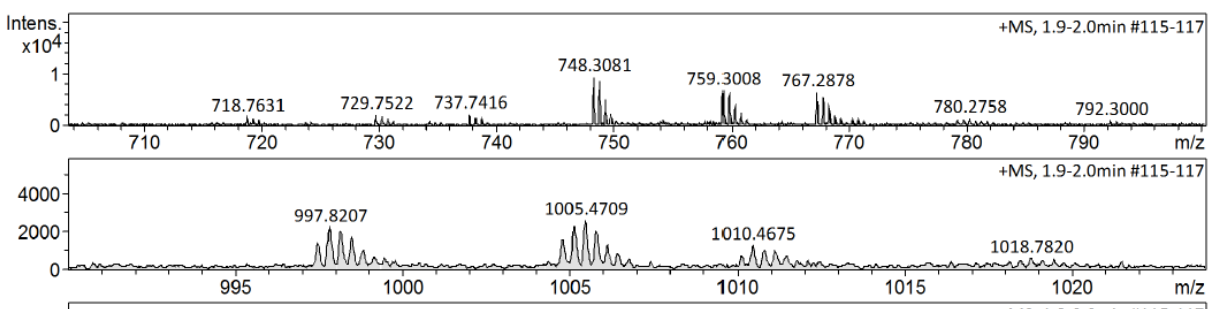

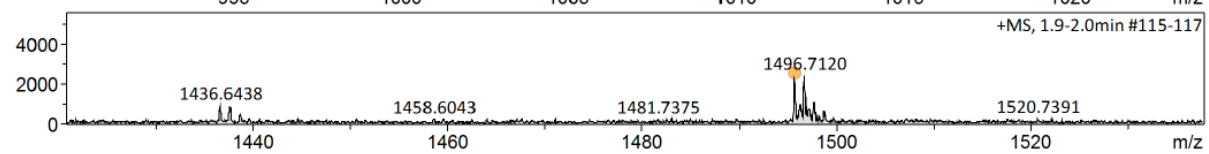

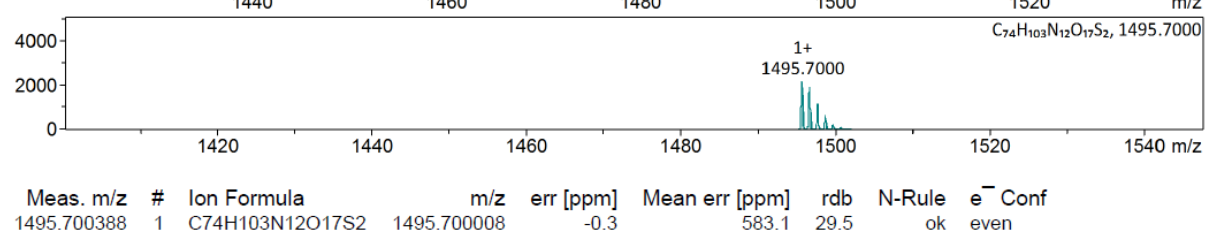

Figure S5. HRMS spectrum of s775z-maleimide 


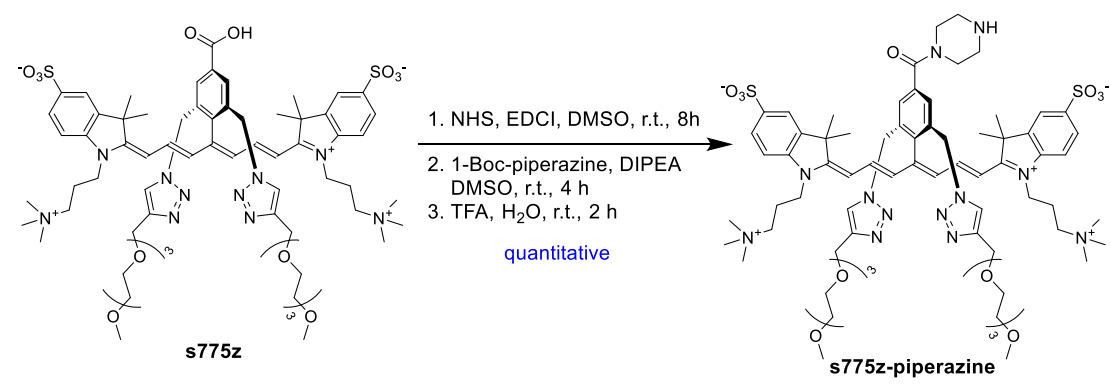

Scheme S4. Synthesis of s775z-piperazine

A mixture of the s775z-NHS, 1-Boc-piperazine ( $3 \mathrm{eq}$ ) and DIPEA (5 eq) in DMSO ( $0.1 \mathrm{~mL}$ for $1 \mathrm{mg}$ of $\mathbf{s 7 7 5 z - N H S}$ ) was stirred at room temperature for $4 \mathrm{~h}$ in the dark. The reaction mixture was transferred into a centrifuge tube. Ethyl acetate ( $5 \mathrm{~mL}$ for $1 \mathrm{~mL}$ of DMSO) was added to the tube and mixture was centrifuged at $3600 \mathrm{rpm}$ for $5 \mathrm{~min}$. The supernatant was discarded and the green solid was washed with ethyl acetate $(2 x)$ and diethyl ether (1x) then dried in vacuo to afford the Boc protected intermediate. The Boc protected intermediate was dissolved in TFA/ $\mathrm{H}_{2} \mathrm{O}$ mixture $(95 / 5,10$ $\mathrm{mg} / \mathrm{mL}$ ) and stirred at room temperature for $2 \mathrm{~h}$ in the dark. TFA and $\mathrm{H}_{2} \mathrm{O}$ was removed under reduced pressure, the residue was washed with acetone and dried to afford s775z-piperazine (green solid, trifluoroacetate salt, quantitative yield).

${ }^{1} \mathrm{H}$ NMR $\left(500 \mathrm{MHz}, \mathrm{D}_{2} \mathrm{O}, 25^{\circ} \mathrm{C}\right) \delta(\mathrm{ppm}): \delta 7.97(\mathrm{~s}, 2 \mathrm{H}), 7.91(\mathrm{~s}, 2 \mathrm{H}), 7.71(\mathrm{~d}, J=8.5 \mathrm{~Hz}, 2 \mathrm{H}), 7.63(\mathrm{~s}, 2 \mathrm{H}), 7.24(\mathrm{~d}, J$ $=8.5 \mathrm{~Hz}, 2 \mathrm{H}), 6.70(\mathrm{~d}, J=13.2 \mathrm{~Hz}, 2 \mathrm{H}), 6.61(\mathrm{dd}, J=13.2,13.2 \mathrm{~Hz}, 2 \mathrm{H}), 6.23(\mathrm{~d}, J=13.2 \mathrm{~Hz}, 2 \mathrm{H}), 5.45(\mathrm{~s}, 4 \mathrm{H}), 4.33$ (s, 4H), $4.07(\mathrm{br} \mathrm{s}, 4 \mathrm{H}), 4.00(\mathrm{~s}, 2 \mathrm{H}), 3.69(\mathrm{~s}, 2 \mathrm{H}), 3.48-3.24(\mathrm{~m}, 28 \mathrm{H}), 3.18(\mathrm{~s}, 6 \mathrm{H}), 3.03(\mathrm{~s}, 18 \mathrm{H}), 2.18(\mathrm{br} \mathrm{s}, 4 \mathrm{H})$, $0.99(\mathrm{~s}, 12 \mathrm{H})$.

HRMS (ESI-TOF) m/z: $[\mathrm{M}+\mathrm{H}]^{2+}$ calcd for $\mathrm{C}_{72} \mathrm{H}_{106} \mathrm{~N}_{12} \mathrm{O}_{15} \mathrm{~S}_{2}{ }^{2+} 721.3666$, found 721.3663 .

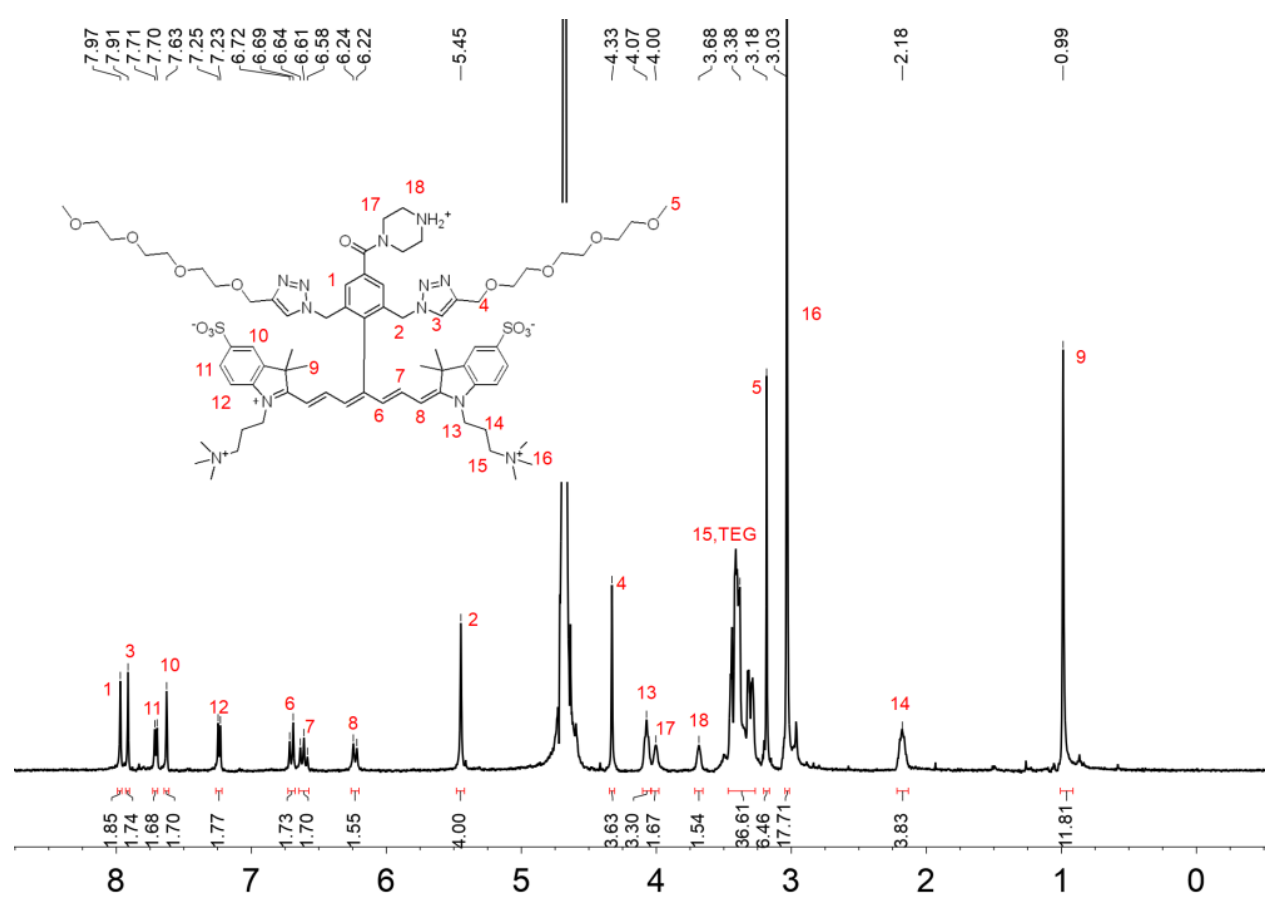

Figure S6. ${ }^{1} \mathrm{H}$ NMR spectrum $\left(500 \mathrm{MHz}, \mathrm{D}_{2} \mathrm{O}, 25^{\circ} \mathrm{C}\right)$ of s775z-piperazine 

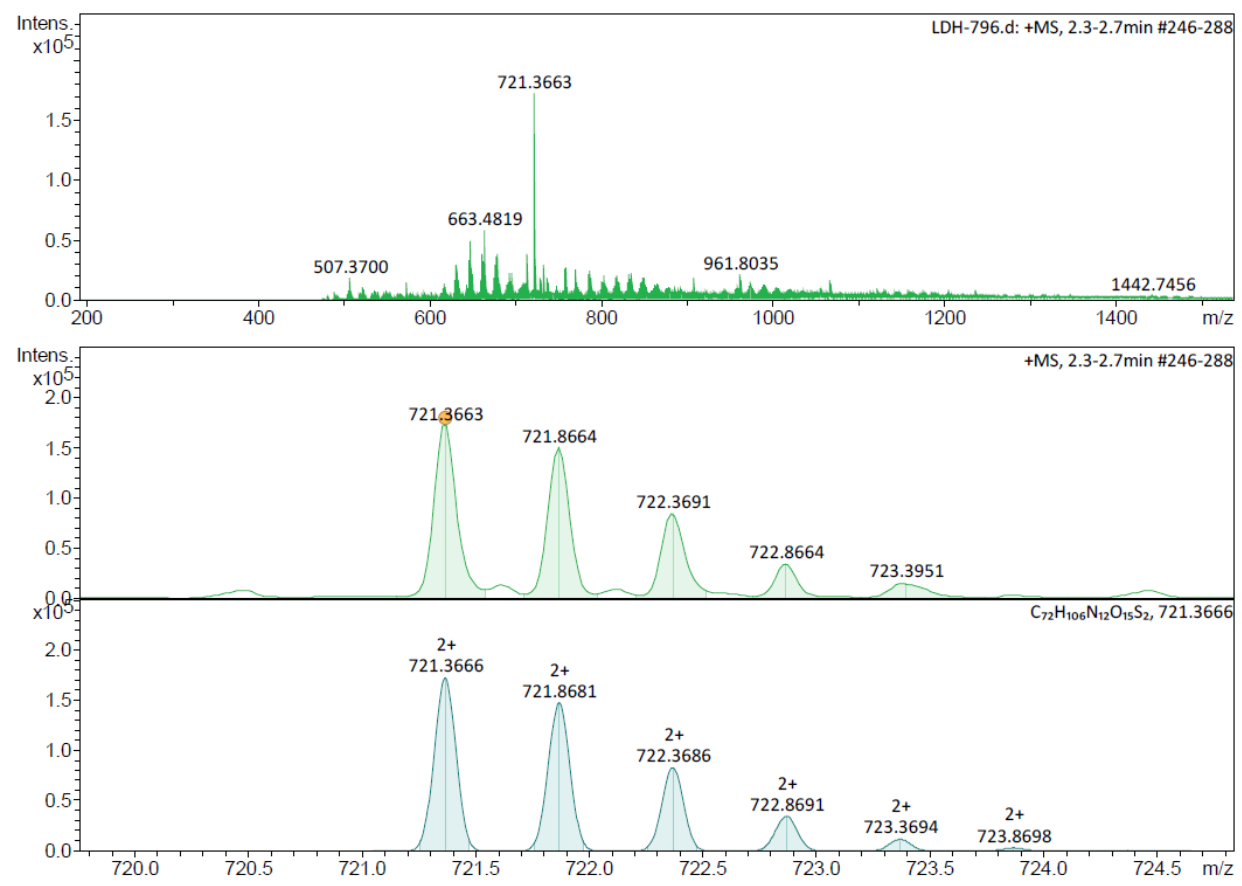

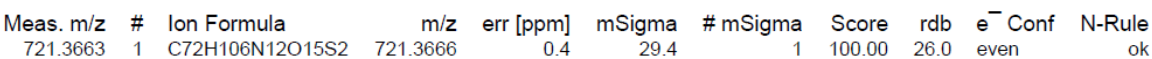

Figure S7. HRMS spectrum of s775z-piperazine
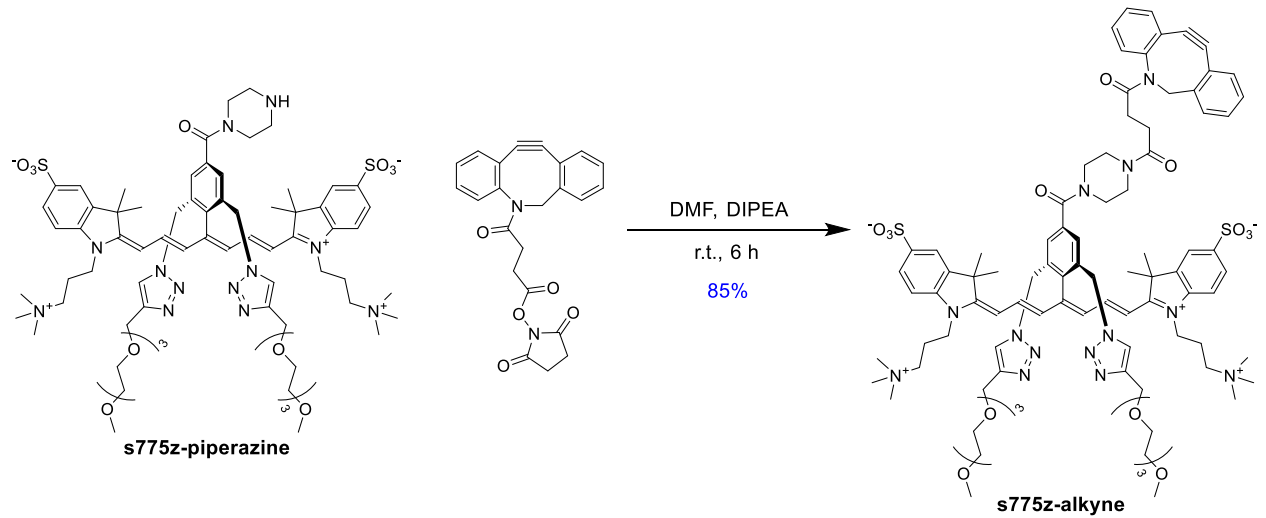

\section{Scheme S5. Synthesis of s775z-alkyne}

A mixture of the s775z-piperazine, DIBAC NHS ester (2 eq) and DIPEA ( 5 eq) in DMF ( $0.2 \mathrm{~mL}$ for $1 \mathrm{mg}$ of s775zpiperazine) was stirred vigorously at room temperature for $6 \mathrm{~h}$ in the dark. The reaction mixture was transferred into a centrifuge tube. Diethyl ether ( $5 \mathrm{~mL}$ for $1 \mathrm{~mL}$ of DMF) was added to the tube and mixture was centrifuged at $3600 \mathrm{rpm}$ for $5 \mathrm{~min}$. The supernatant was discarded and the green solid was washed with Diethyl ether serval times and dried to afford s775z-alkyne (green solid, $85 \%$ yield).

HRMS (ESI-TOF) m/z: [M+Na] ${ }^{2+}$ calcd for $\mathrm{C}_{91} \mathrm{H}_{118} \mathrm{~N}_{13} \mathrm{O}_{17} \mathrm{~S}_{2} \mathrm{Na}^{2+} 857.9048$, found 857.9050 . 


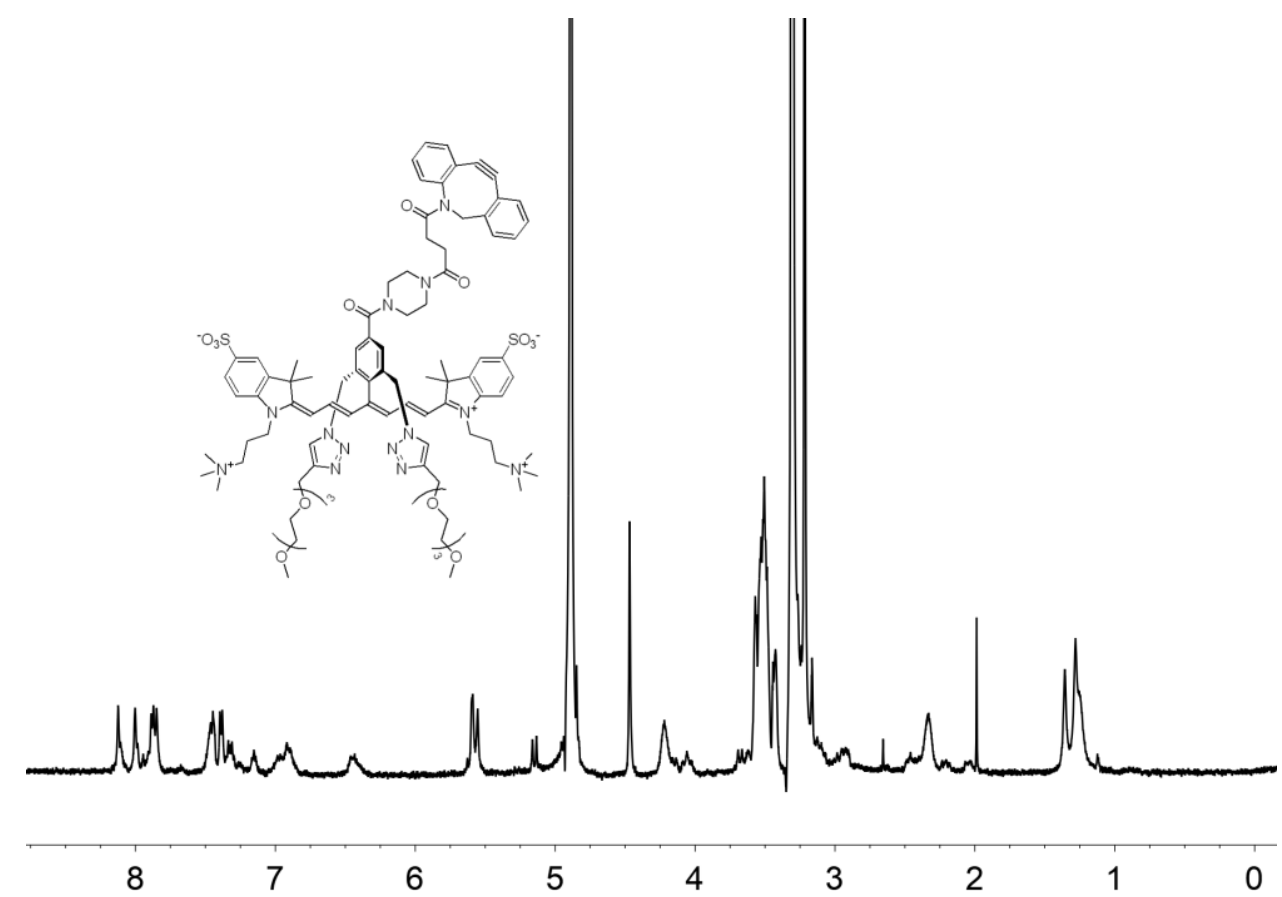

Figure S8. ${ }^{1} \mathrm{H}$ NMR spectrum $\left(500 \mathrm{MHz}\right.$, methanol- $\left.d_{4}, 25^{\circ} \mathrm{C}\right)$ of $\mathbf{s} 775 z$-alkyne

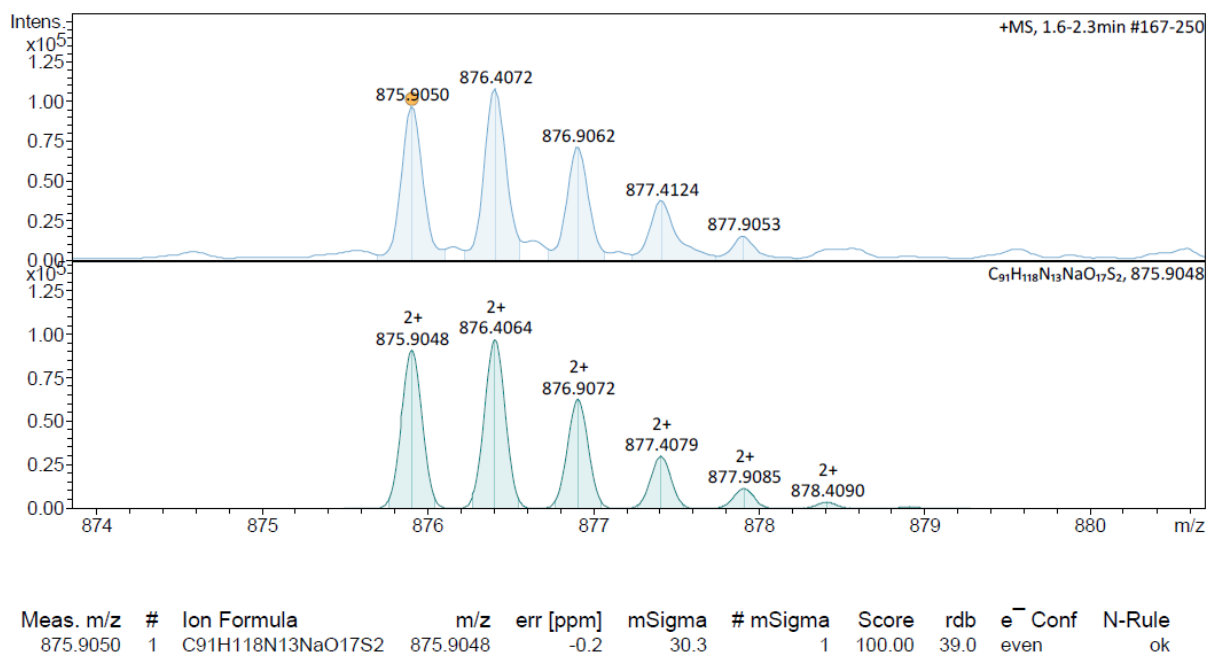

Figure S9. HRMS spectrum of s775z-alkyne 


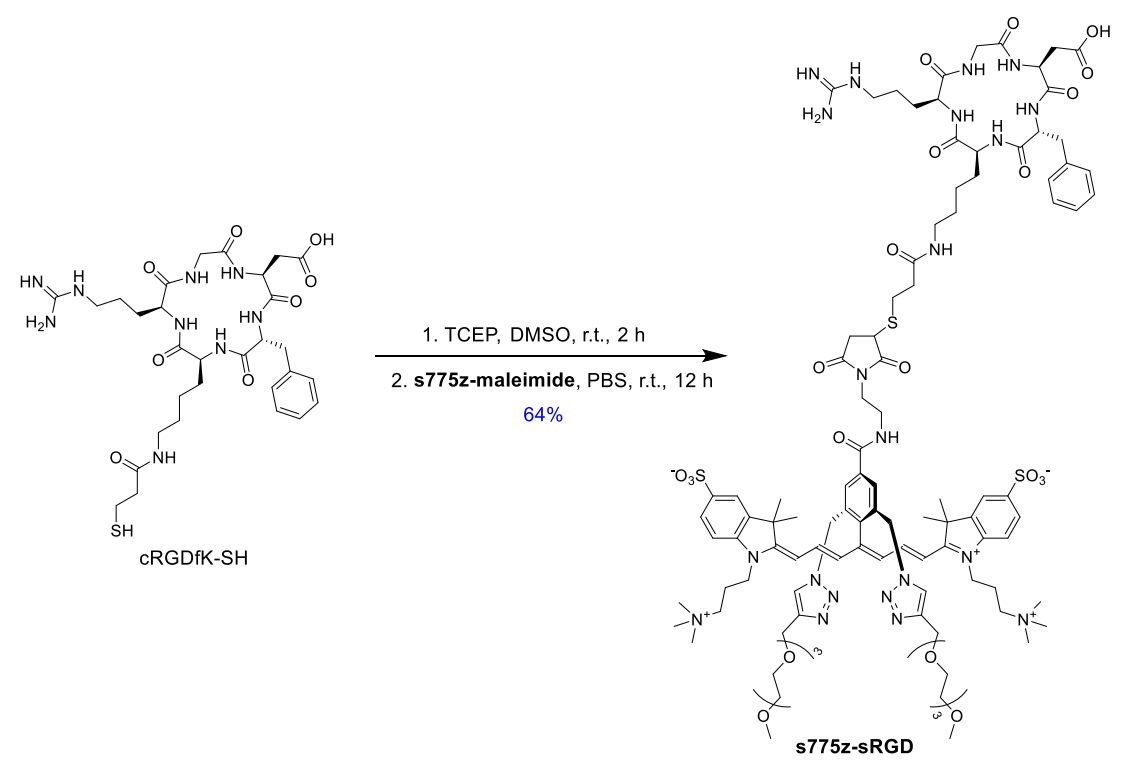

Scheme S6. Synthesis of s775z-sRGD

Thiol cRGDfK-SH is dissolved in DMSO. Then TCEP (freshly prepared, $1 \mathrm{M} \mathrm{in} \mathrm{H}_{2} \mathrm{O}, 0.5$ eq) was added. The solution was stirred at room temperature for $2 \mathrm{~h}$ under nitrogen atmosphere. A solution of $\mathbf{s} 775 \mathrm{z}$-maleimide $(2 \mathrm{eq})$ in PBS buffer $(\mathrm{pH} 7.4,10 \mathrm{mg} / \mathrm{mL})$ was added. The mixture was stirred at room temperature for $12 \mathrm{~h}$ under nitrogen atmosphere in the dark. The product was purified by reverse-phase column chromatography (C18) to give s775z-sRGD.

Important notes: free thiol forms disulfide in air, which is usually reduced by TCEP before thiol-maleimide coupling. However, excess phosphine can quench the heptamethine fluorophore. ${ }^{6}$ Therefore, only 0.5 equiv. of TCEP was used and the coupling was performed in PBS buffer to quench excess TCEP (TCEP is unstable in phosphate buffer). All solvents were bubbled with nitrogen before usage.

Green solid, $64 \%$ yield, reverse phase column chromatography: $\mathrm{C} 18,20-50 \% \mathrm{MeOH}$ contains $0.5 \%$ TFA in $\mathrm{H}_{2} \mathrm{O}$.

HRMS (ESI-TOF) m/z: [M] calcd for $\mathrm{C}_{104} \mathrm{H}_{149} \mathrm{~N}_{21} \mathrm{O}_{25} \mathrm{~S}_{3}{ }^{+} 2188.0190$, found 2188.0193 .

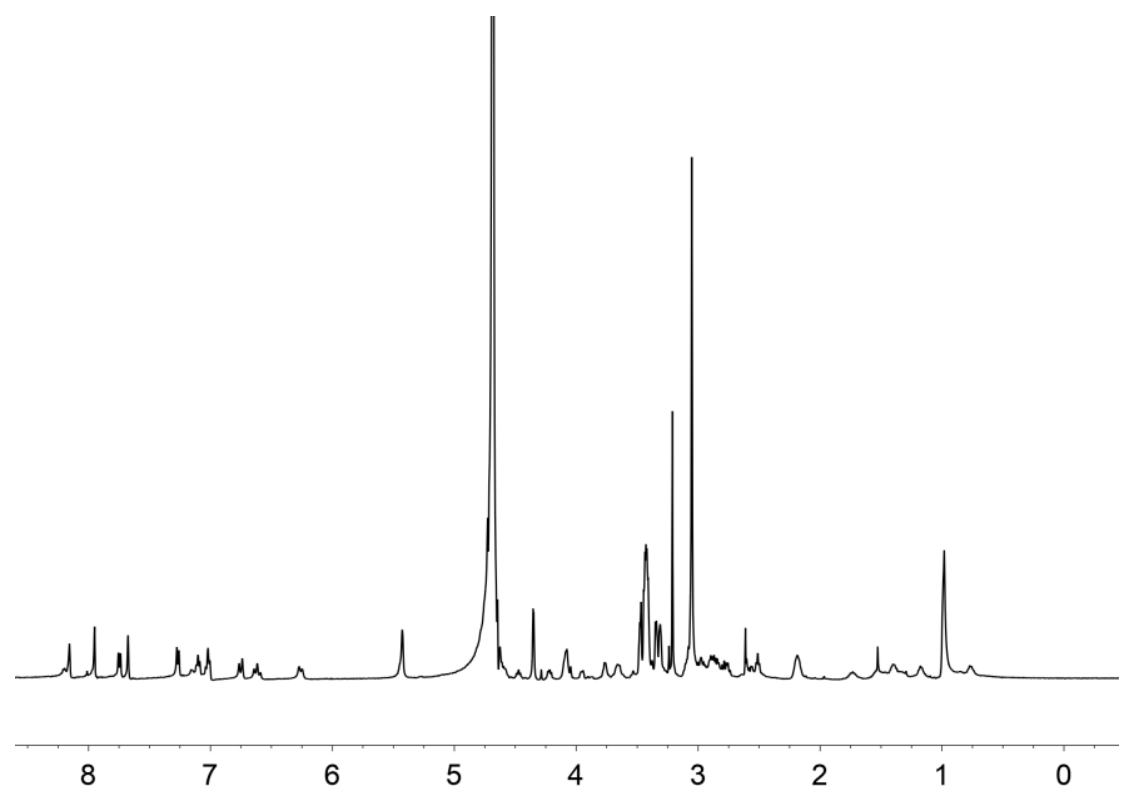

Figure S10. ${ }^{1} \mathrm{H}$ NMR spectrum $\left(500 \mathrm{MHz}, \mathrm{D}_{2} \mathrm{O}, 25^{\circ} \mathrm{C}\right)$ of $\mathbf{s} 775 z-s R G D$ 

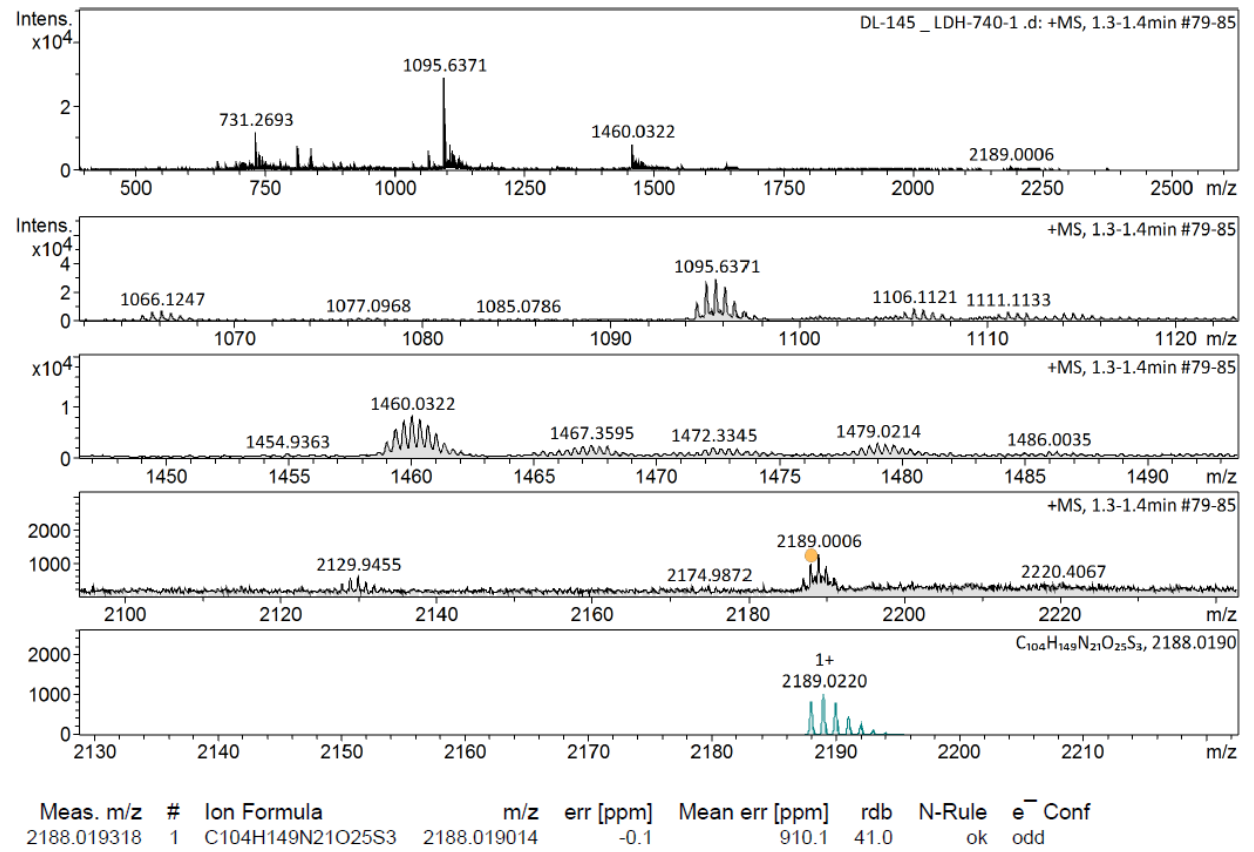

Figure S11. HRMS spectrum of s775z-sRGD

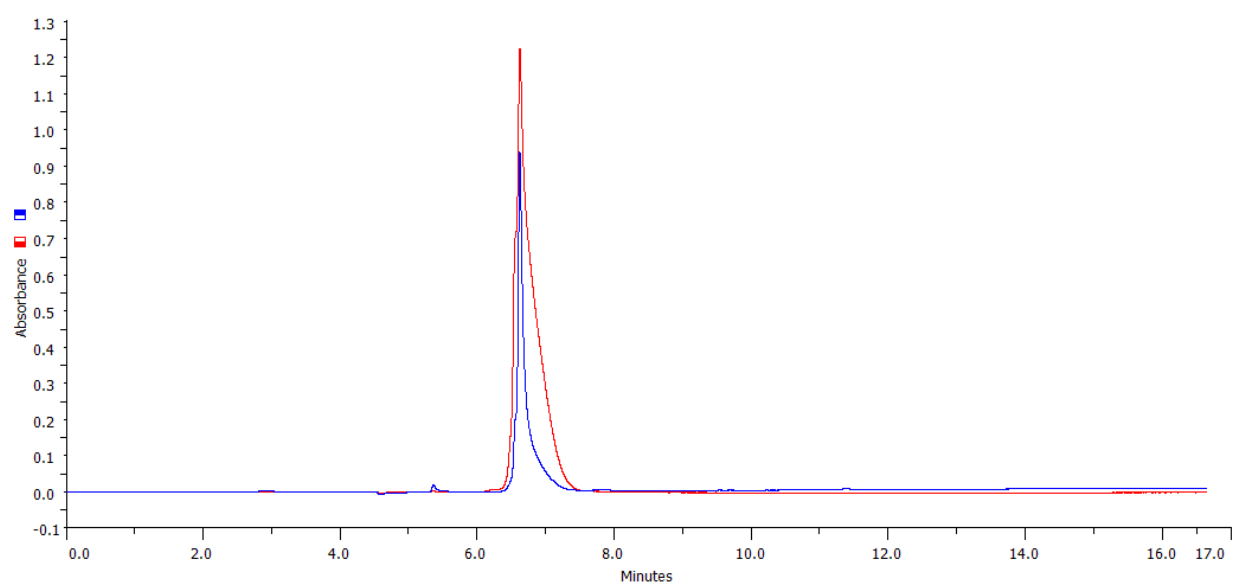

Figure S12. HPLC spectrum of s775z-sRGD showing high purity. Solvent: $0-95 \%$ acetonitrile in water with $0.1 \%$ TFA; flow rate: $1 \mathrm{~mL} / \mathrm{min}$; detector: $750 \mathrm{~nm}$ (red) and $260 \mathrm{~nm}$ (blue). Purity: 98\%. 

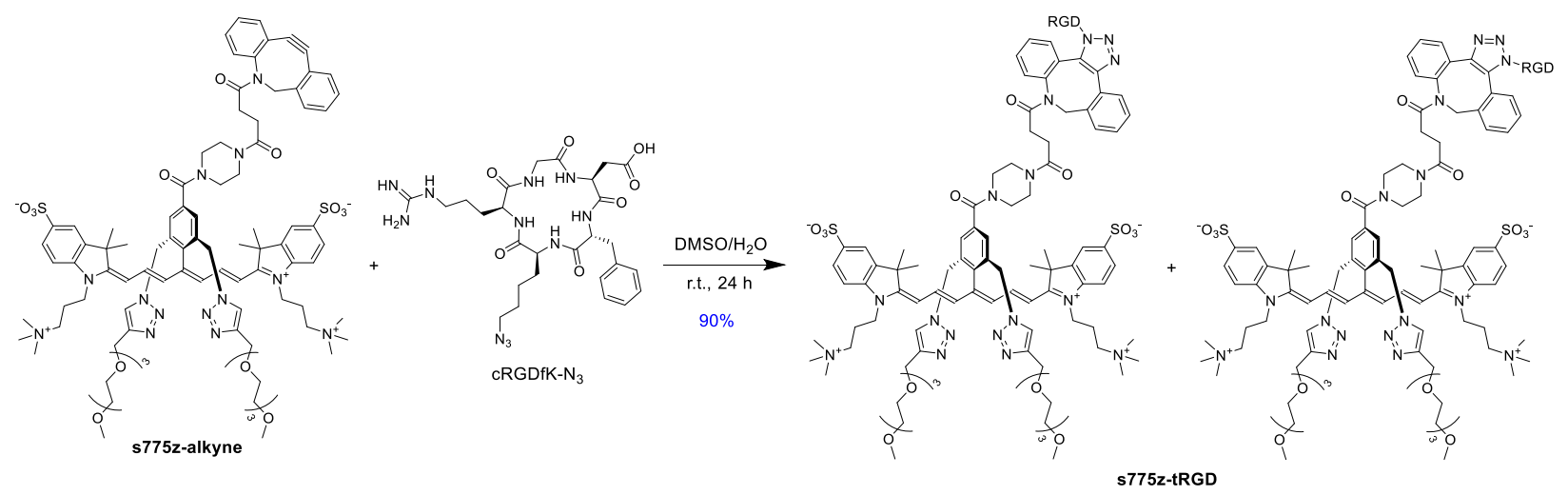

Scheme S7. Synthesis of s775z-tRGD

A solution of azide cRGDfK- $\mathrm{N}_{3}\left(\mathrm{MeOH}\right.$, DMSO, or $\mathrm{H}_{2} \mathrm{O}$, depends on the solubility of azide) was added to a solution of s775z-alkyne in water or DMSO (make sure there is no insoluble material in the mixture). The mixture was stirred at room temperature for $24 \mathrm{~h}$ in the dark. After that the mixture was directly purified by reverse phase column chromatography to give s775z-tRGD.

Green solid, $90 \%$ yield, reverse phase column chromatography: C18, 40-60\% $\mathrm{MeOH}$ contains $0.5 \%$ TFA in $\mathrm{H}_{2} \mathrm{O}$.

HRMS (ESI-TOF) m/z: $[M+H]^{2+}$ calcd for $\mathrm{C}_{118} \mathrm{H}_{159} \mathrm{~N}_{24} \mathrm{O}_{24} \mathrm{SS}_{2}{ }^{2+}$ 1180.0695, found 1180.0689 .

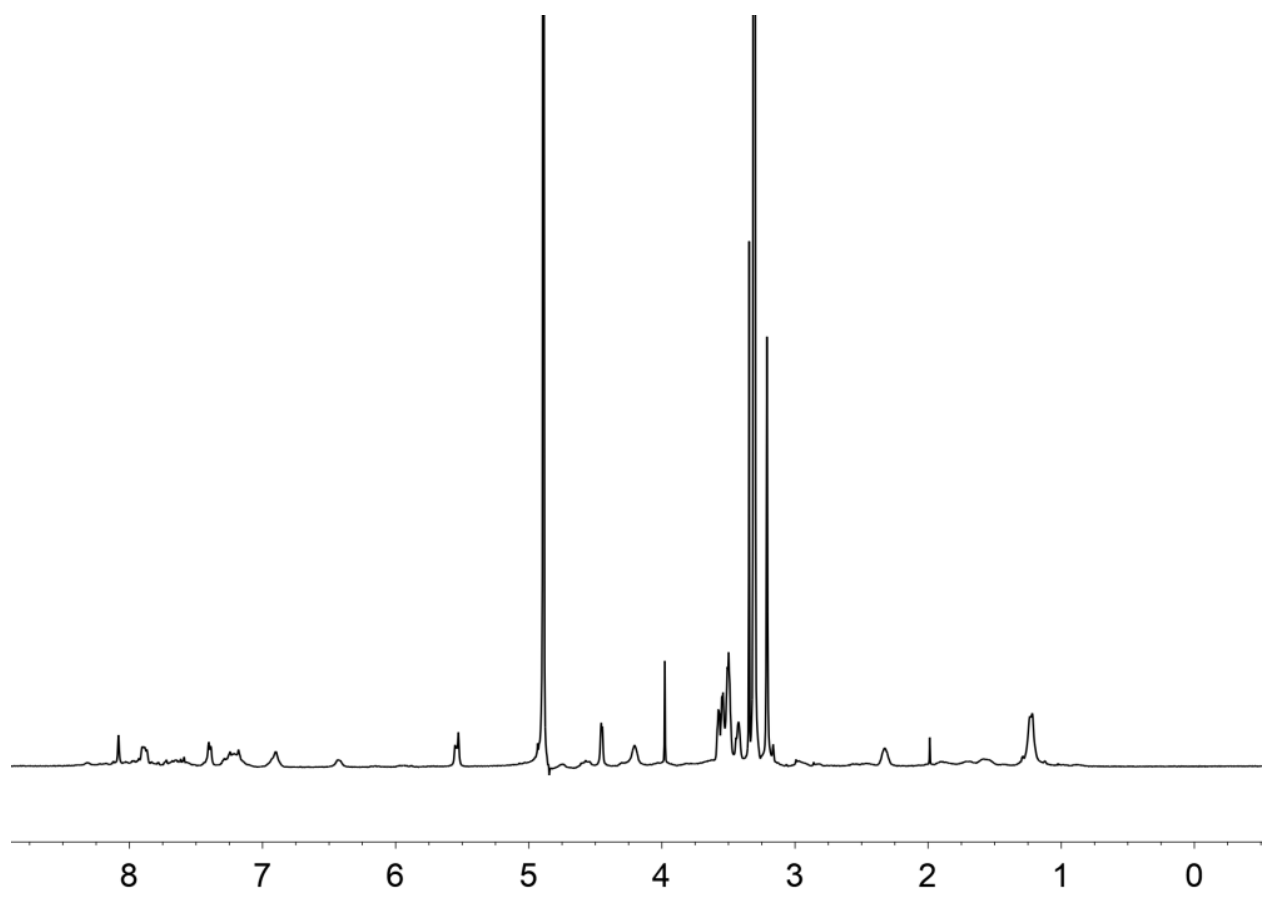

Figure S13. ${ }^{1} \mathrm{H}$ NMR spectrum $\left(500 \mathrm{MHz}, \mathrm{D}_{2} \mathrm{O}, 25^{\circ} \mathrm{C}\right)$ of $\mathbf{s} 775 z-t R G D$ 

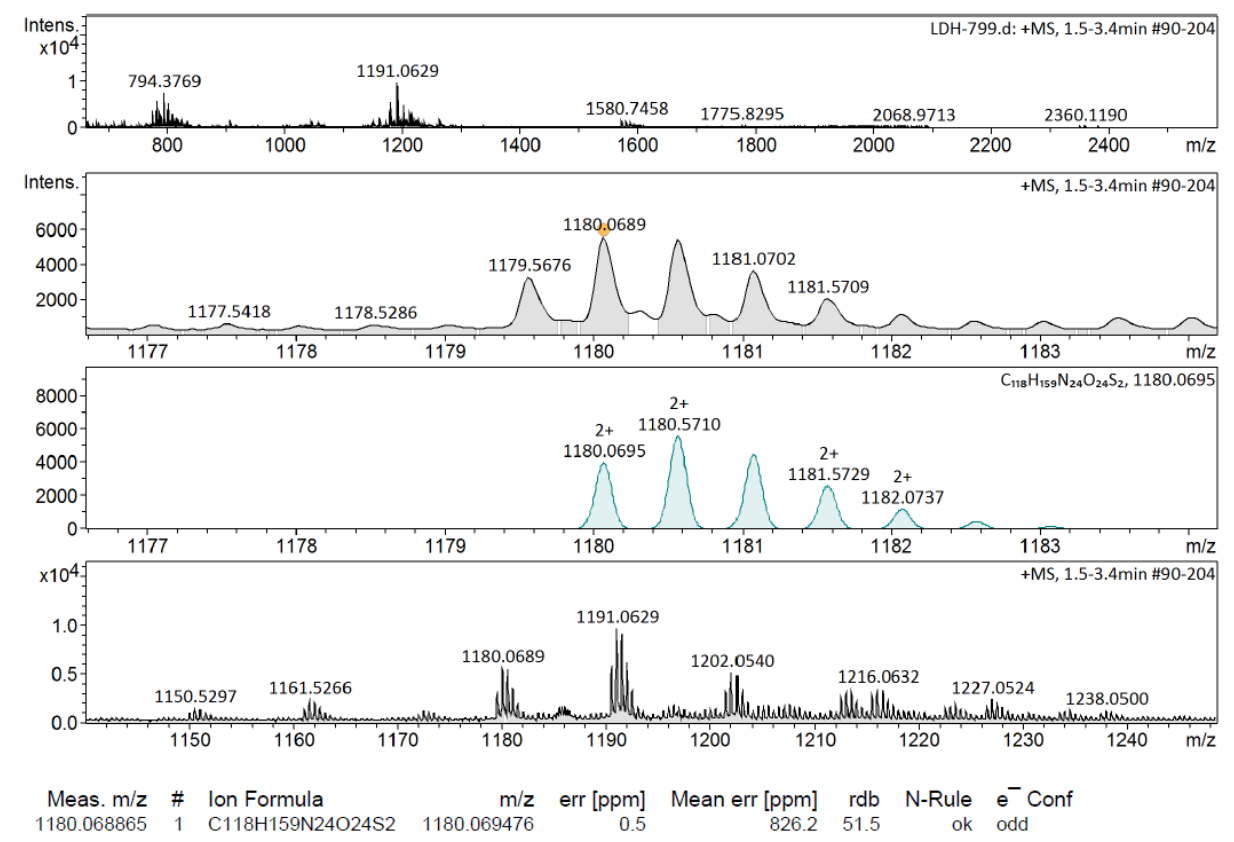

Figure S14. HRMS spectrum of s775z-tRGD

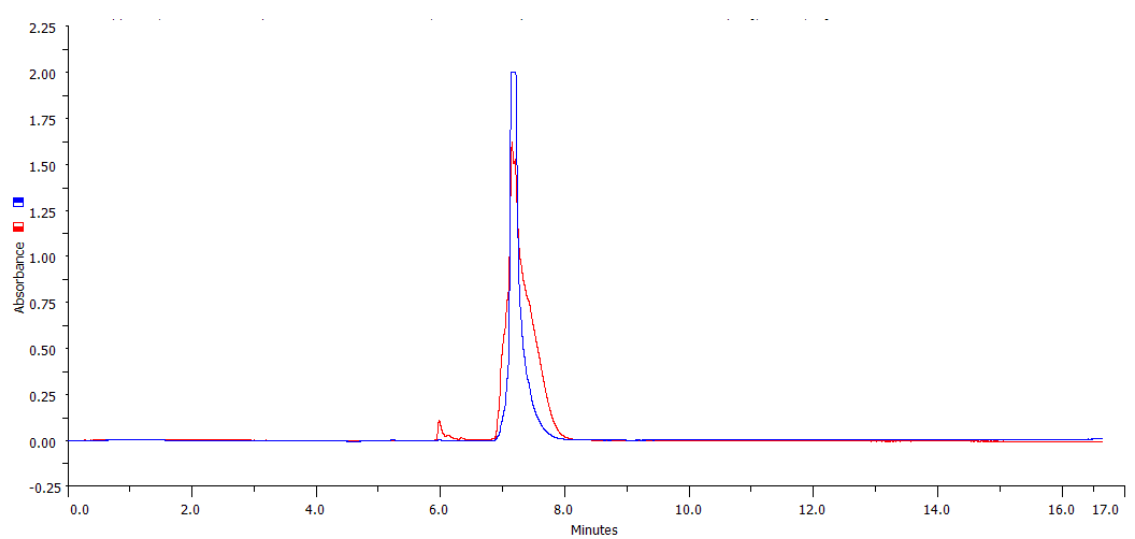

Figure S15. HPLC spectrum of s775z-tRGD showing high purity. Solvent: $0-95 \%$ acetonitrile in water with $0.1 \%$ TFA; flow rate: $1 \mathrm{~mL} / \mathrm{min}$; detector: $750 \mathrm{~nm}$ (red) and $260 \mathrm{~nm}$ (blue). Purity: $95 \%$. 


\section{Photophysical Properties}

Analyte solutions were prepared in phosphate buffered saline (Thermo Fisher. All absorption and fluorescence spectra were collected using quartz cuvettes ( $1 \mathrm{~mL}, 1 \mathrm{~cm}$ path length; for emission and excitation spectra, slit width $=3 \mathrm{~nm}$ ).

Quantum yield measurements used $\mathbf{s 7 7 5 z}\left(\Phi_{\mathrm{F}}=9.0 \%\right.$ in $\left.\mathrm{pH} 7.4 \mathrm{PBS}\right)$ as a reference standard. ${ }^{1}$ The concentrations of $\mathbf{s} 775 \mathrm{z}$ and other cyanine dyes were adjusted to the absorption value of 0.08 at $730 \mathrm{~nm}$. The fluorescence spectrum of each solution was obtained with excitation at $730 \mathrm{~nm}$, and the integrated area was used in the quantum yield calculation by the following equation:

$$
\Phi_{\text {sample }}=\Phi_{\text {ref }} \times \frac{\eta_{\text {sample }}^{2} I_{\text {sample }} A_{\text {sample }}}{\eta_{\text {ref }}^{2} I_{\text {ref }} A_{\text {ref }}}
$$

where $\eta$ is the refractive index of the solvent, $I$ is the integrated fluorescence intensity, and $A$ is the absorbance at a chosen wavelength. The estimated error for this method is $\pm 10 \%$.

Table S1. Chemical properties of fluorescent probes.

\begin{tabular}{ccccc}
\hline Dye $^{a}$ & $\mathrm{MW}(\mathrm{g} / \mathrm{mol})$ & $\mathrm{pK}_{\mathrm{a}}, \mathrm{H}_{2} \mathrm{O}^{b}$ & $\mathrm{LogP}^{c}$ & $\mathrm{LogD}, \mathrm{pH} 7.4^{c}$ \\
\hline $\mathbf{s 7 7 5 z}$ & 1373.69 & 9.27 & -2.41 & -4.72 \\
$\mathbf{s 7 7 5 z - a R G D}$ & 1959.36 & 9.44 & -7.03 & -10.84 \\
$\mathbf{s 7 7 5 z - s R G D}$ & 2187.62 & 9.42 & -8.23 & -12.04 \\
$\mathbf{s 7 7 5 z - t R G D}$ & 2358.81 & 9.73 & -5.21 & -9.02 \\
650z & 785.03 & 8.02 & -3.02 & -5.65 \\
\hline
\end{tabular}

${ }^{a}$ Carboxylic acid residues were deprotonated when preforming calculation. ${ }^{b}$ Calculated in BondEnergy software. ${ }^{7,8}{ }^{c}$ Calculated in ChemAxon Chemicalize software. ${ }^{9}$ 

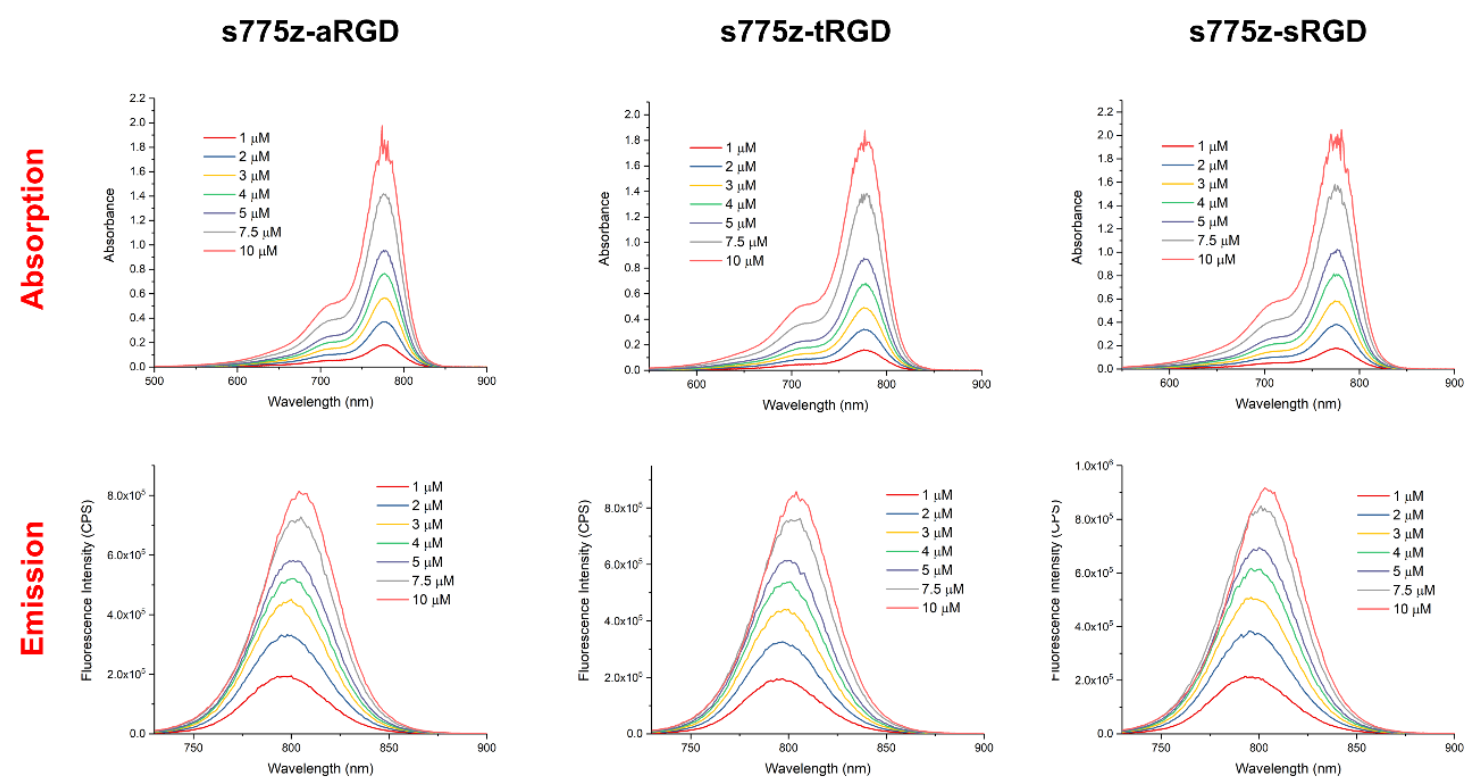

Figure S16. Spectral properties and absorption-emission spectra of s775z-aRGD, s775z-sRGD, and s775z-tRGD at different concentrations (pH 7.4 PBS buffer at room temperature). $\lambda_{\mathrm{ex}}=720 \mathrm{~nm}$, slit width $=3 \mathrm{~nm}$. 


\section{Bovine Serum Albumin Binding Studies}

(a)
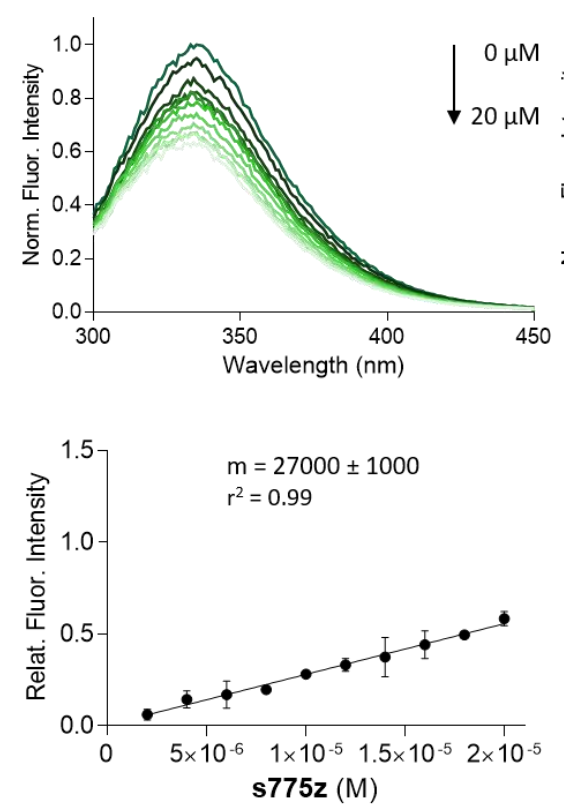

(c)
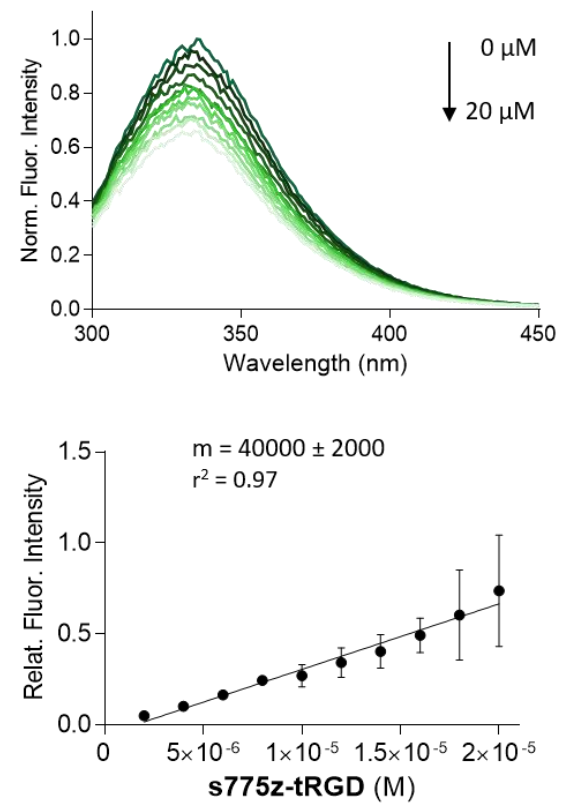

(b)
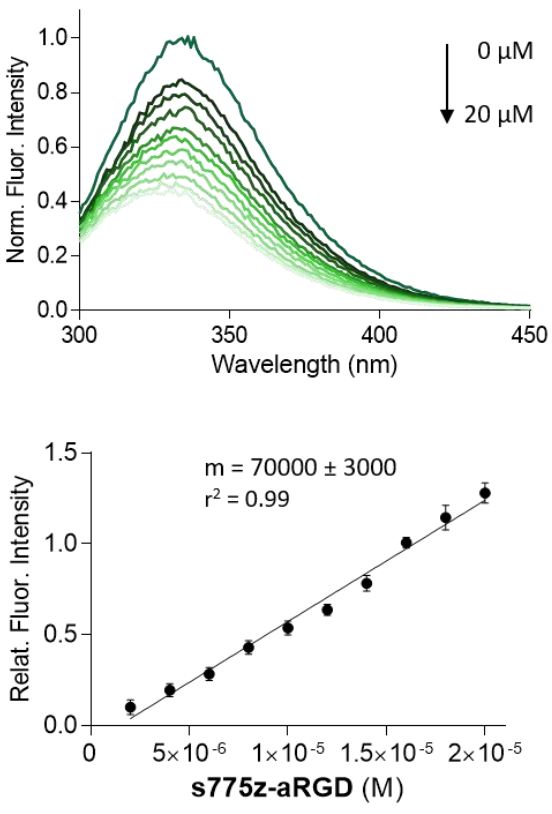

(d)
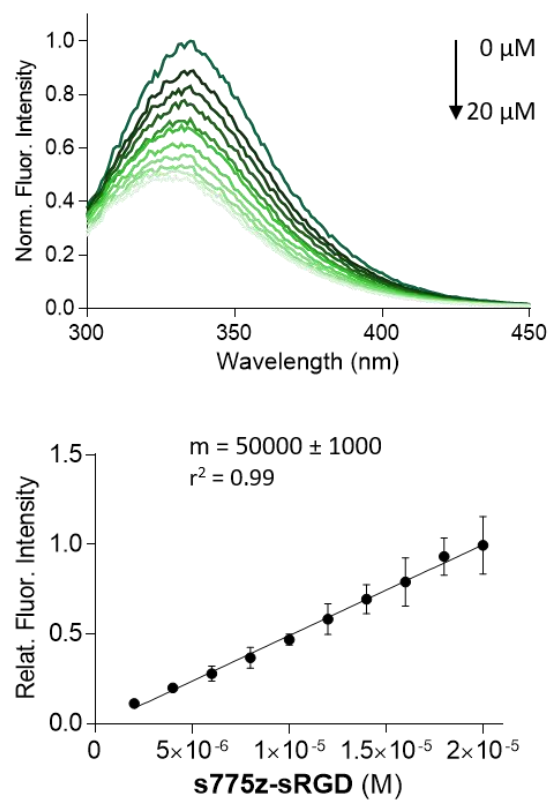

Figure S17. Dye/BSA association studies of: (a) s775z, (b) s775z-aRGD, (c) s775z-tRGD and (d) s775z-sRGD in water at $37^{\circ} \mathrm{C}$. Aliquots $(4 \mu \mathrm{L})$ of probe stock solution $(1 \mathrm{mM})$ was added to $2 \mathrm{~mL}$ of $2 \mu \mathrm{M} \mathrm{BSA}$, thus varying the probe concentration from 0-20 $\mu \mathrm{M}$. BSA tryptophan fluorescence intensity (excitation: $280 \mathrm{~nm}$; slit width: $2 \mathrm{~nm}$ ) was plotted as a function of the dye concentration to obtain association constants $K_{a}$ where $m=K_{a} \pm S D\left(M^{-1}\right)$. 


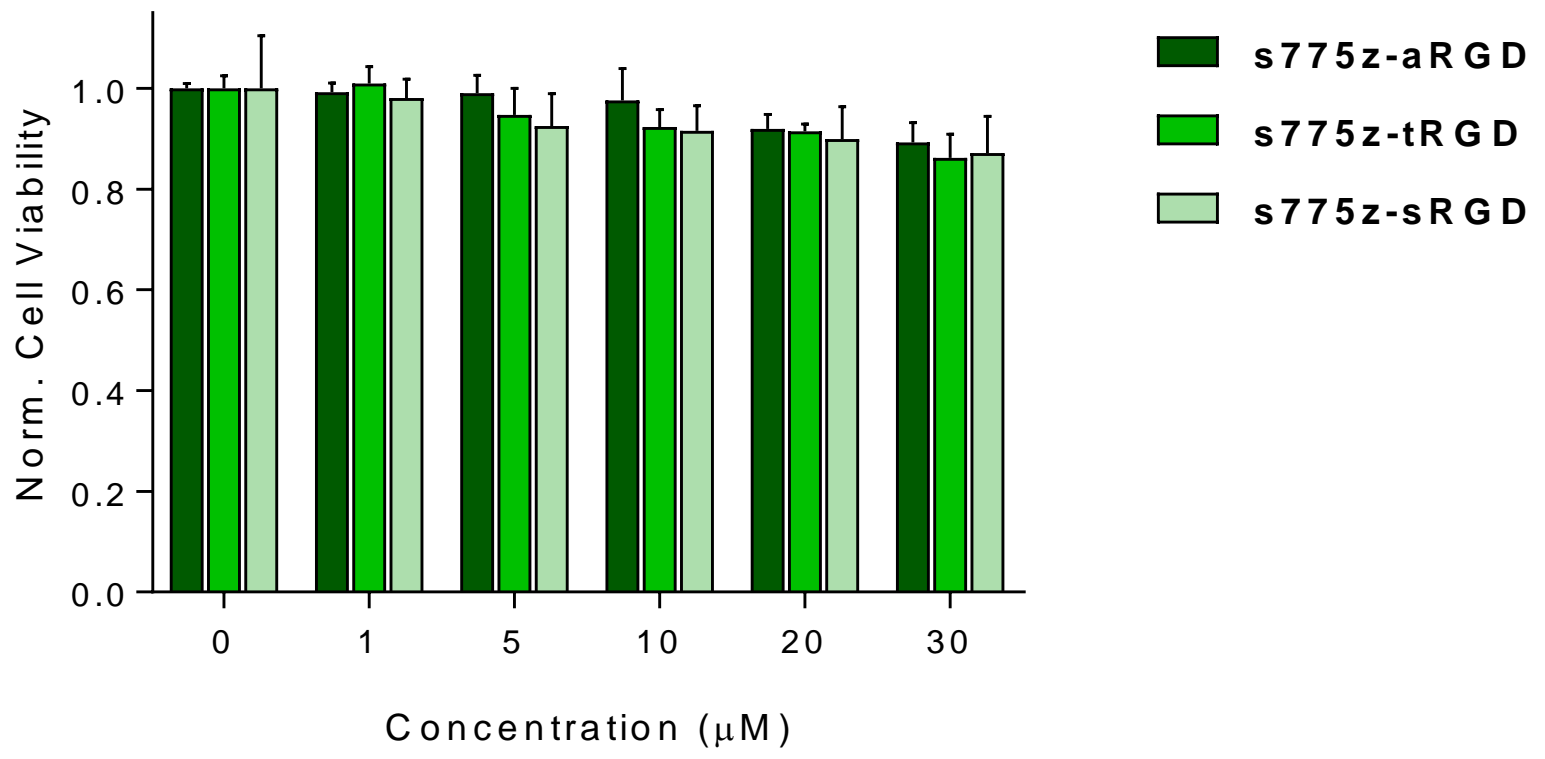

Figure S18. MTT cell viability assays of s775z-aRGD, s775z-sRGD, and s775z-tRGD. Separate wells containing A549 cells were treated with one of the probes for $24 \mathrm{hr}$ at $37{ }^{\circ} \mathrm{C}$ and $5 \% \mathrm{CO}_{2}$. Readings are normalized to untreated cells and reflect triplicate experiments. 


\section{In vivo Imaging Studies}
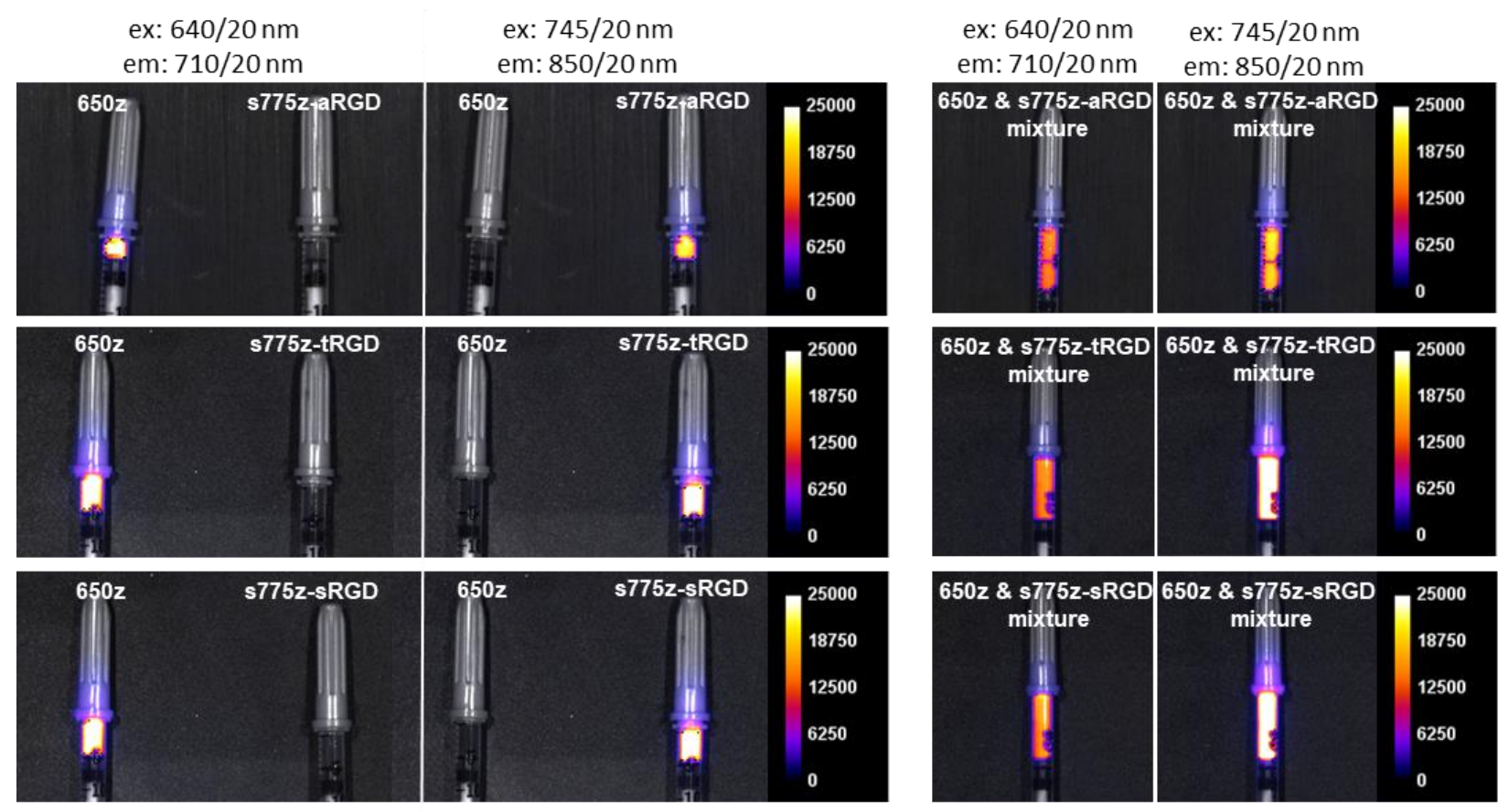

ex: $745 / 20 \mathrm{~nm}$

em: $850 / 20 \mathrm{~nm}$
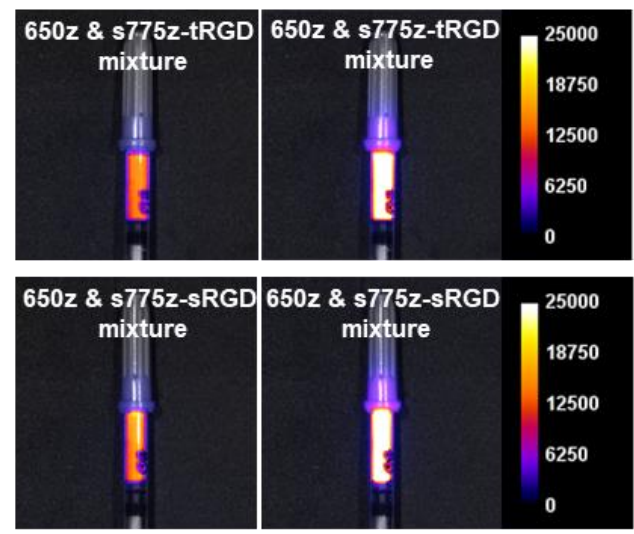

Figure S19. Fluorescent and brightfield images of syringes containing: (left pane/) dilute aqueous solution of $650 z$ dye or one of the $s 775 z$ probes; (right panel) binary $1: 1$ mixture of $650 z$ dye and one of the s $775 z$ probes. Images acquired using in vivo imaging station with two different filter settings [(ex: 640/20 nm, em: 710/20 nm, exposure: $3 \mathrm{~s}$, percent power: 50\%, F-stop: 2, FOV:20, binning: low) or (ex: 745/20 nm, em: 850/20 nm, exposure: $3 \mathrm{~s}$, percent power: 50\%, F-stop: 2, FOV:20, binning: low)]. 
(a)

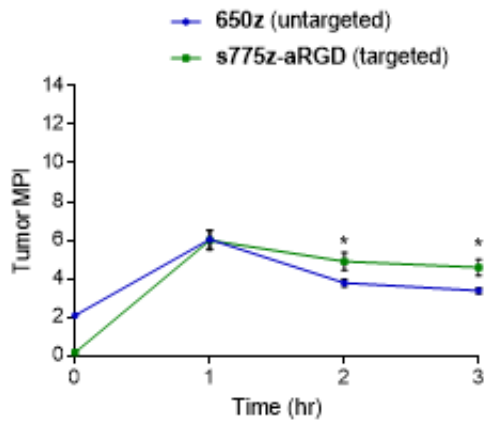

(b)

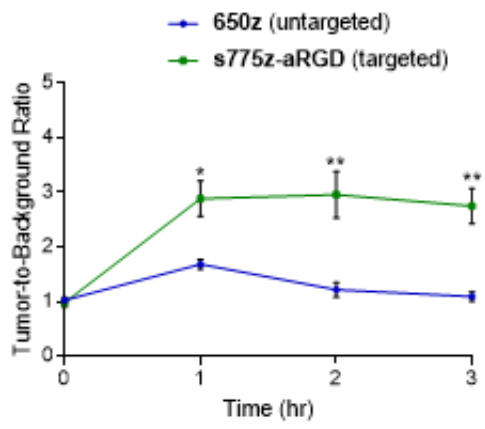

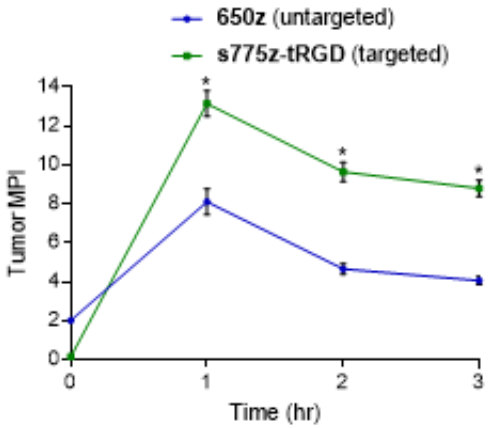

- $650 \mathrm{z}$ (untargeted)

- s775z-tRGD (targeted)

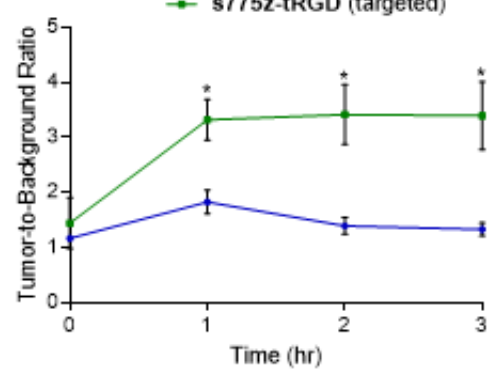

$\rightarrow 650 \mathrm{z}$ (untargeted)

- s775z-sRGD (targeted)

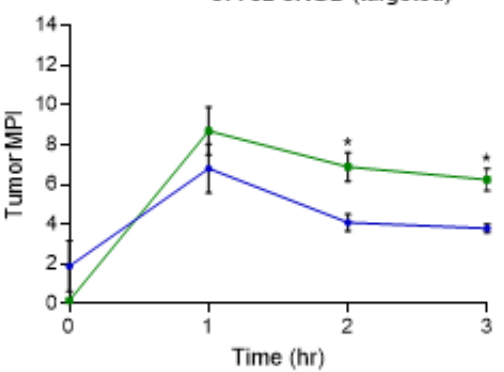

- $650 \mathrm{z}$ (untargeted)

- s775z-sRGD (targeted)

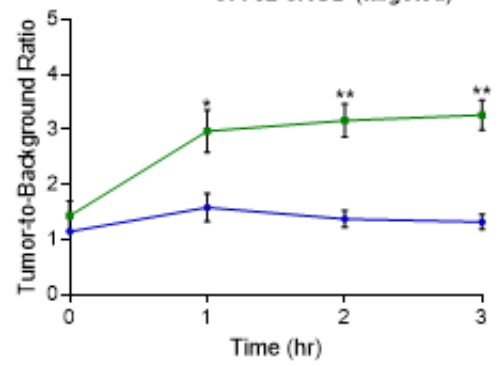

Figure S20. (a) Tumor Mean Pixel Intensity (MPI), and (b) Tumor-to-Background Ratio for living mice bearing subcutaneous tumor (human A549 lung adenocarcinoma), after intravenous co-injection of $650 z$ dye and one of the s775z probes (s775z-aRGD, s775z-tRGD or s775z-sRGD) (20nmol/mouse). *indicates $p \leq 0.05,{ }^{* *} p<0.01$ 


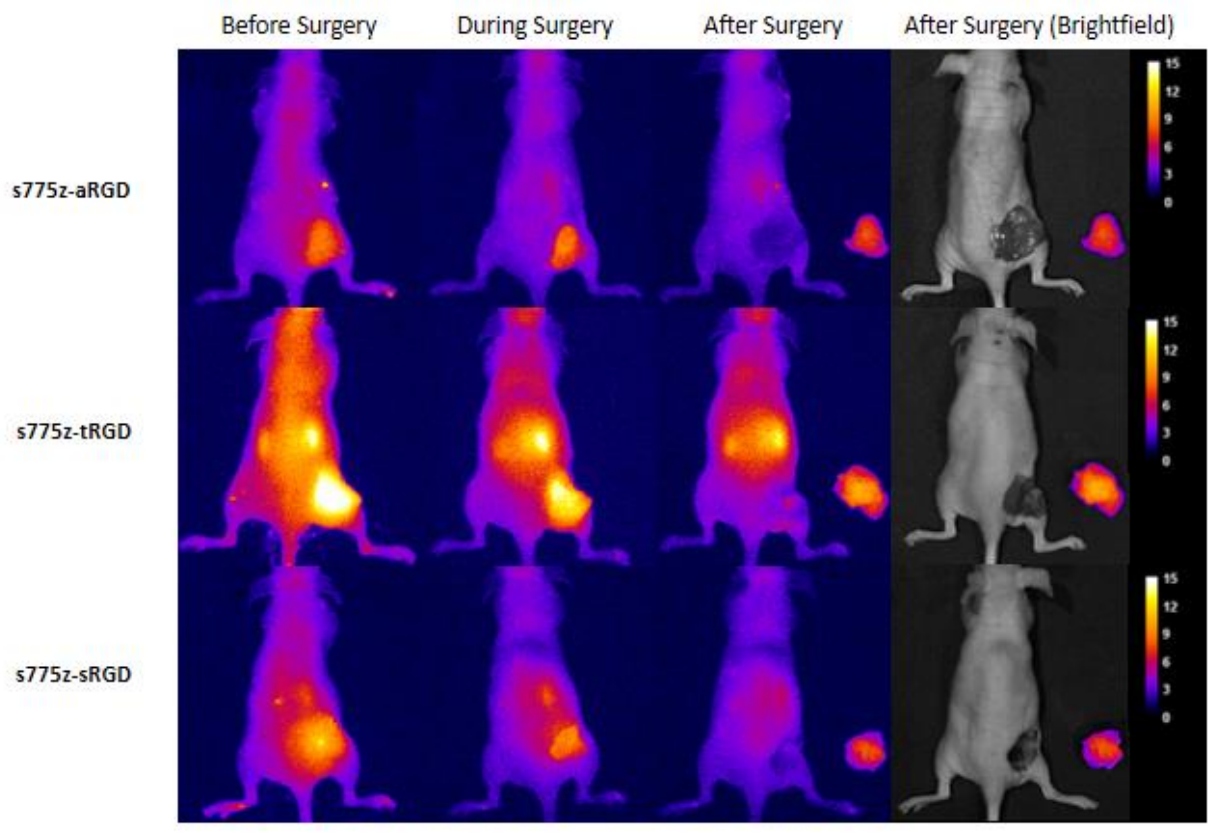

Figure S21. Mock surgery process using a tumor-bearing mouse at $3 \mathrm{~h}$ post injection of s775z-aRGD, s775z-tRGD or s775z-sRGD. Representative images were taken Before Surgery (living mouse), During Surgery (sacrificed mouse with surrounding skin removed) and After Surgery (excised tumor next to the sacrificed mouse body). 
(a)

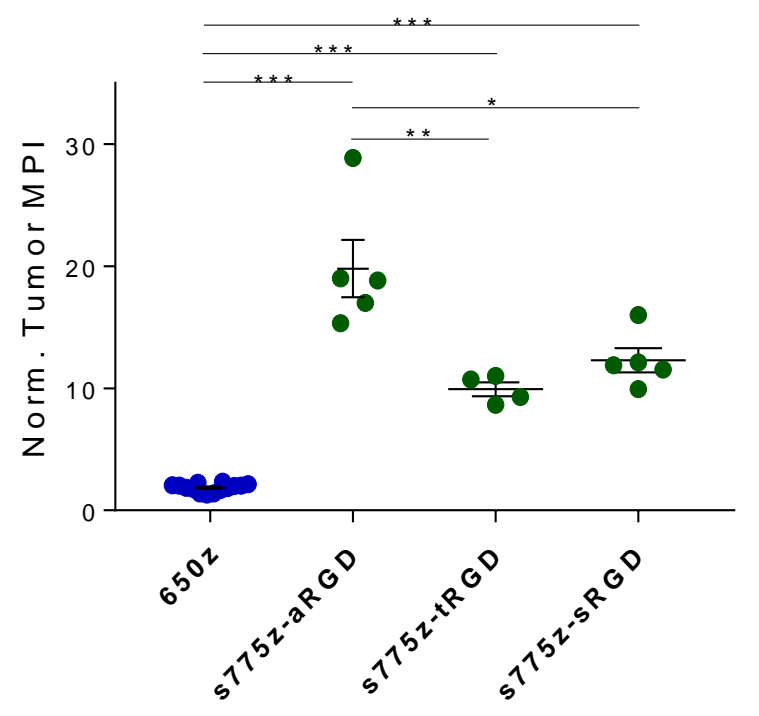

(b)

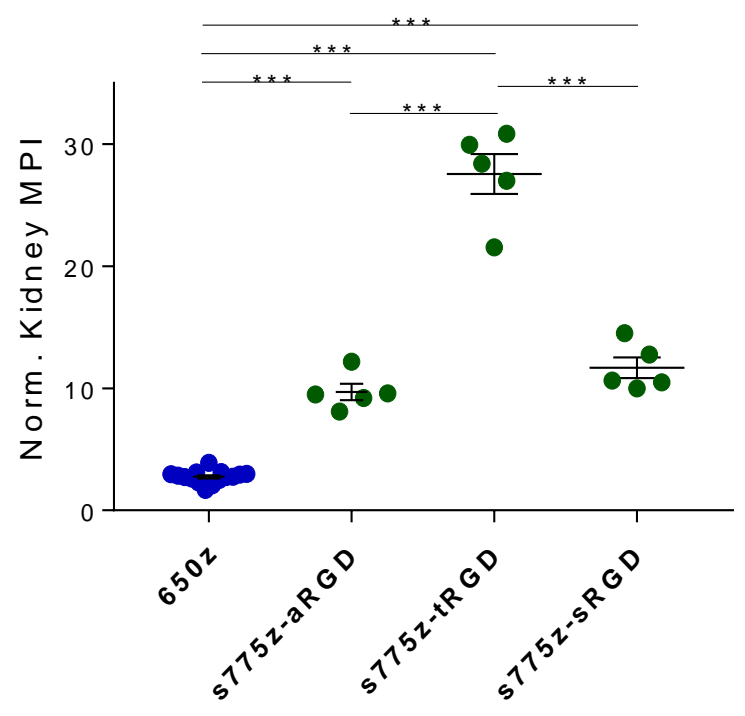

Figure S22. Expansion of the biodistribution data in article Figure 3. The normalized mean pixel intensity (MPI) for untargeted $650 \mathrm{z}$ and each of the three targeted $\mathrm{s} 775 \mathrm{z}$ probes in the excised: (a) tumor tissue, or (b) kidney tissue. The MPI values for each probe are normalized to the thigh muscle MPI from the same animal ( $N=5$ for each probe). Fluorescence filter settings for the untargeted $650 z$ [(ex: $640 / 20 \mathrm{~nm}$, em: 710/20 nm, exposure time: $3 \mathrm{sec}$, percent power: 50\%, F-stop: 2, FOV: 20, binning - low) and targeted s $775 \mathrm{z}$ probes (ex: $745 / 20 \mathrm{~nm}$, em: 850/20 nm, exposure time: $3 \mathrm{sec}$, percent power: 50\%, F-stop: 2, FOV: 20, binning - low). The average for each cohort $(\mathrm{N}=5)$ is indicated by the black line with error bars representing \pm SEM. ${ }^{*}$ indicates $p<0.05,{ }^{* *} p<0.01,{ }^{* * *} p<0.001$ 


\section{References}

(1) Li, D.; Schreiber, C. L.; Smith, B. D. Sterically Shielded Heptamethine Cyanine Dyes for Bioconjugation and High Performance Near-Infrared Fluorescence Imaging. Angew. Chem. Int. Ed. 2020, 59, 12154-12161. https://doi.org/10.1002/anie.202004449.

(2) Campbell-Verduyn, L. S.; Mirfeizi, L.; Schoonen, A. K.; Dierckx, R. A.; Elsinga, P. H.; Feringa, B. L. StrainPromoted Copper-Free "Click" Chemistry for ${ }^{18} \mathrm{~F}$ Radiolabeling of Bombesin. Angew. Chem. Int. Ed. 2011, 50, 11117-11120. https://doi.org/10.1002/anie.201105547.

(3) Ma, X.; Cheng, K.; Wu, B.; Duan, J.; Chen, H.; Bu, L.; Zhang, R.; Hu, X.; Deng, Z.; Xing, L.; et al. Strained Cyclooctyne as a Molecular Platform for Construction of Multimodal Imaging Probes. Angew. Chem. Int. Ed. 2015, 54, 5981-5984. https://doi.org/10.1002/anie.201500941.

(4) Li, H.; Zhou, H.; Krieger, S.; Parry, J. J.; Whittenberg, J. J.; Desai, A. V; Rogers, B. E.; Kenis, P. J. A.; Reichert, D. E. Triazine-Based Tool Box for Developing Peptidic PET Imaging Probes: Syntheses, Microfluidic Radiolabeling, and Structure- Activity Evaluation. Bioconjug. Chem. 2014, 25, 761-766. https://doi.org/10.1021/bc500034n.

(5) Hyun, H.; Henary, M.; Gao, T.; Narayana, L.; Owens, E. A.; Lee, J. H.; Park, G.; Wada, H.; Ashitate, Y.; Frangioni, J. V; et al. 700-Nm Zwitterionic Near-Infrared Fluorophores for Dual-Channel Image-Guided Surgery. Mol. Imaging Biol. 2016, 18, 52-61. https://doi.org/10.1007/s11307-015-0870-4.

(6) Vaughan, J. C.; Dempsey, G. T.; Sun, E.; Zhuang, X. Phosphine Quenching of Cyanine Dyes as a Versatile Tool for Fluorescence Microscopy. J. Am. Chem. Soc 2013, 135, 1197-1200. https://doi.org/10.1021/ja3105279.

(7) Yang, Q.; Li, Y.; Yang, J.; Liu, Y.; Zhang, L.; Luo, S.; Cheng, J. Holistic Prediction of pKa in Diverse Solvents Based on Machine Learning Approach Intermediates. Angew. Chem. Int. Ed. 2020, 59, 19282-19291.

(8) BioEnergy. pKa Predictions. http://pka.luoszgroup.com/prediction (accessed on Sep. 26, 2021)

(9) ChemAxon. Chemicialize Sofware. https://chemicalize.com/app/calculation (accessed on Sep 26, 2021) 